\title{
STRUCTURAL-COMPOSITIONAL MODEL OF THE NYURBINSKAYA KIMBERLITE PIPE FORMATION (SREDNE-MARKHA AREA OF THE YAKUTIAN DIAMONDIFEROUS PROVINCE)
}

\author{
A. S. Gladkov¹, D. A. Koshkarev1, A. V. Cheremnykh1, F. João², \\ M. A. Karpenko's, ${ }^{\text {, M. V. Marchuk }}{ }^{1}$, I. A. Potekhina ${ }^{1}$ \\ ${ }^{1}$ Institute of the Earth's Crust, Siberian Branch of RAS, Irkutsk, Russia \\ ${ }^{2}$ Sociedade Mineira de Catoca (Catoca Ltd.), Luanda, Angola \\ ${ }^{3} S C$ «ALROSA» (PC), Mirny, Russia
}

Abstract: The paper presents the results of comprehensive study of the primary diamond deposit of the Nyurbinskaya pipe in the Yakutian diamondiferous province. It is established, that the pipe is confined to the fault junction of four directions and is composed of the kimberlite of four phases. Analysis of different faults and tectonic fracturing allowed to reconstruct the tectonic stress fields acting at the stage of the kimberlite body formation and to determine their occurrence sequence in time. The data obtained about regularities of the Nyurbinskaya pipe compositional structure and results of geologo-structural studies are combined in a single structural-compositional model of the deposit formation. Peculiarities of the fault network operation during the deposit formation stage are confirmed by experimental results using polarization-optical method. The model allowed to formulate the basic structural characteristics of the prospecting works object within which the formation of kimberlite body type of the Nyurbinskaya pipe is possible and to determine the elements of the fault network which are promising for the kimberlite pipes discovery.

Key words: kimberlites; Yakutian diamondiferous province; structural-tectonic model; structural-compositional model

Recommended by D.P. Gladkochub

For citation: Gladkov A.S., Koshkarev D.A., Cheremnykh A.V., João F., Karpenko M.A., Marchuk M.V., Potekhina I.A. 2016. Structural-compositional model of the Nyurbinskaya kimberlite pipe formation (Sredne-Markha area of the Yakutian Diamondiferous Province). Geodynamics \& Tectonophysics 7 (3), 435-458. doi:10.5800/GT-2016-7-3-0216.

\section{СТРУКТУРНО-ВЕЩЕСТВЕННАЯ МОДЕЛЬ СТАНОВЛЕНИЯ КИМБЕРЛИТОВОЙ ТРУБКИ НЮРБИНСКАЯ (СРЕДНЕ-МАРХИНСКИЙ РАЙОН ЯКУТСКОЙ АЛМАЗОНОСНОЙ ПРОВИНЦИИ)}

\author{
А. С. Гладков ${ }^{1}$, Д. А. Кошкарев ${ }^{1}$, А. В. Черемных ${ }^{1}$, Ф. Жоао ${ }^{2}$, \\ М. А. Карпенко ${ }^{2,3}$, М. В. Марчук ${ }^{1}$, И. А. Потехина 1 \\ ${ }^{1}$ Институт земной коры СО РАН, Иркутск, Россия \\ ${ }^{2}$ Sociedade Mineira de Catoca (Catoca Ltd.), Luanda, Angola \\ ${ }^{3}$ АК «АЛРОСА» (ПАО), Мирный, Россия
}

Аннотация: В статье представлены результаты комплексного изучения коренного месторождения алмазов трубка Нюрбинская. Установлено, что трубка приурочена к узлу разломов четырех направлений и сложена 
кимберлитами четырех фаз. Анализ разноранговых разрывных нарушений и тектонической трещиноватости позволил восстановить поля тектонических напряжений, действовавшие на этапе формирования кимберлитового тела и определить последовательность их проявления во времени. Полученные данные о закономерностях вещественного строения трубки Нюрбинской и результаты геолого-структурных исследований объединены в рамках единой структурно-вещественной модели формирования месторождения. Особенности функционирования разрывной сети на этапе формирования месторождения подтверждены результатами экспериментов с использованием поляризационно-оптического метода. Полученная модель позволила сформулировать признаки, определяющие основные структурные характеристики объекта поисковых работ, в пределах которого возможно формирование кимберлитовых тел типа трубки Нюрбинской, и на их основании выделить те элементы разломной сети (разломные узлы), которые являются перспективными для обнаружения кимберлитовых трубок.

Ключевые слова: кимберлиты; Якутская алмазоносная провинция; структурно-тектоническая модель; структурно-вещественная модель

\section{INTRODUCTION}

Available models of the structure and formation of the primary diamond deposits within the Yakutian province are for the most part based both on the findings of investigation of the kimberlite bodies composition and deep inclusions enclosed in them. Much less attention was given to the problems of structural characteristics of the diamondiferous pipes location. Well studied substance and a distinct lack of structural data are typical of the majority of known deposits as well as of generalized models of diamondiferous kimberlite pipe of the Yakutian province [Kharkiv et al., 1998]. The absence of structural component reduces scientific and practical value of modeling. Comprehensive studies of compositional and structural components of the primary diamond deposits structure are requisite. Team building of experts in various fields to conduct joint field and cameral works and as well as a comprehensive consideration, analysis and interpretation of the data obtained is the most promising aim of this inquiry. The present work deals with results of the use of such integrated approach to the Nyurbinskaya pipe localization study where the tectonic and compositional structure studies were conducted within the quarry field over 10 years.

\section{BRIEF DESCRIPTION OF STUDIED OBJECT}

The Nakyn kimberlite field which includes the Nyurbinskaya pipe is located within the Nakyn and Markha Rivers interfluve. The field position is determined by junction of the Vilyui-Markha and SredneMarkha zones of regional faults [Kondratiev, Gorev, 2005], therefore, the faults of NE and NWdirections play the primary role in the Nakyn kimberlite field structure (Fig. 1). Kimberlite bodies of the Nakyn field are characterized by chain position and lie practically in one line with NE direction of $25-30^{\circ}$. It is believed that Diyakhtarsky and Botuobinsky faults are the main ore controlling structures of the field (Fig. 1) [Kondratiev, Gorev, 2005]. The Diagonalnyi fault situated approximately at $30^{\circ}$ to the above mentioned faults serves as kimberlite enclosing structure. This fault has been recognized according to the seismic sounding data [Sablukov et al., 2008], as well as microstructural indications in the hole core [Ignatov et al., 2008].

The Nyurbinskaya pipe is located in the upper river of the Dyulyung-Otu creek (right tributary of the Nakyn River) on the north-eastern end of the chain of the Nakyn field bodies near the axial line of the Botuobinsky fault (Fig. 1). It penetrates the Upper Cambrian and Lower Ordovician aleurolite-argillo-carbonate sediments and is overlapped by the cover of the Lower-Middle Jurassic sediments (ukugutskaya, tyungskaya and suntarskaya sequences) and by the Middle-Late Triassic disintegrated products of crusts of weathering with total thickness of 55-60 m (Fig. 2). The kimberlite body is elliptical in plan and elongated in the NNE direction. The pipe structure is complicated by the subalkaline trapp intrusion roof of which is observed by holes of core boring in central and southern parts of the pipe at depths from 296 up to $332 \mathrm{~m}$ [Kharkiv et al., 1998]. The intrusion emplacement in consolidated kimberlite rocks caused formation of metasomatically modified kimberlites along its contacts.

The Nyurbinskaya pipe is considered in most of published works [Bogatikov et al., 2004; Tomshin et al., 1998, Chernyi et al., 1998] as two-phase kimberlite body composed of porphyric micaceous kimberlites (the first, intrusive phase) and eruptive autolith kimberlite breccias (the second, explosive phase) which almost completely compose the diatreme. More complex pipe structure is proposed in other publications [Sablukov et al., 2008; Sablukov et al., 2010]; and in the ore body composition are distinguished up to 5 


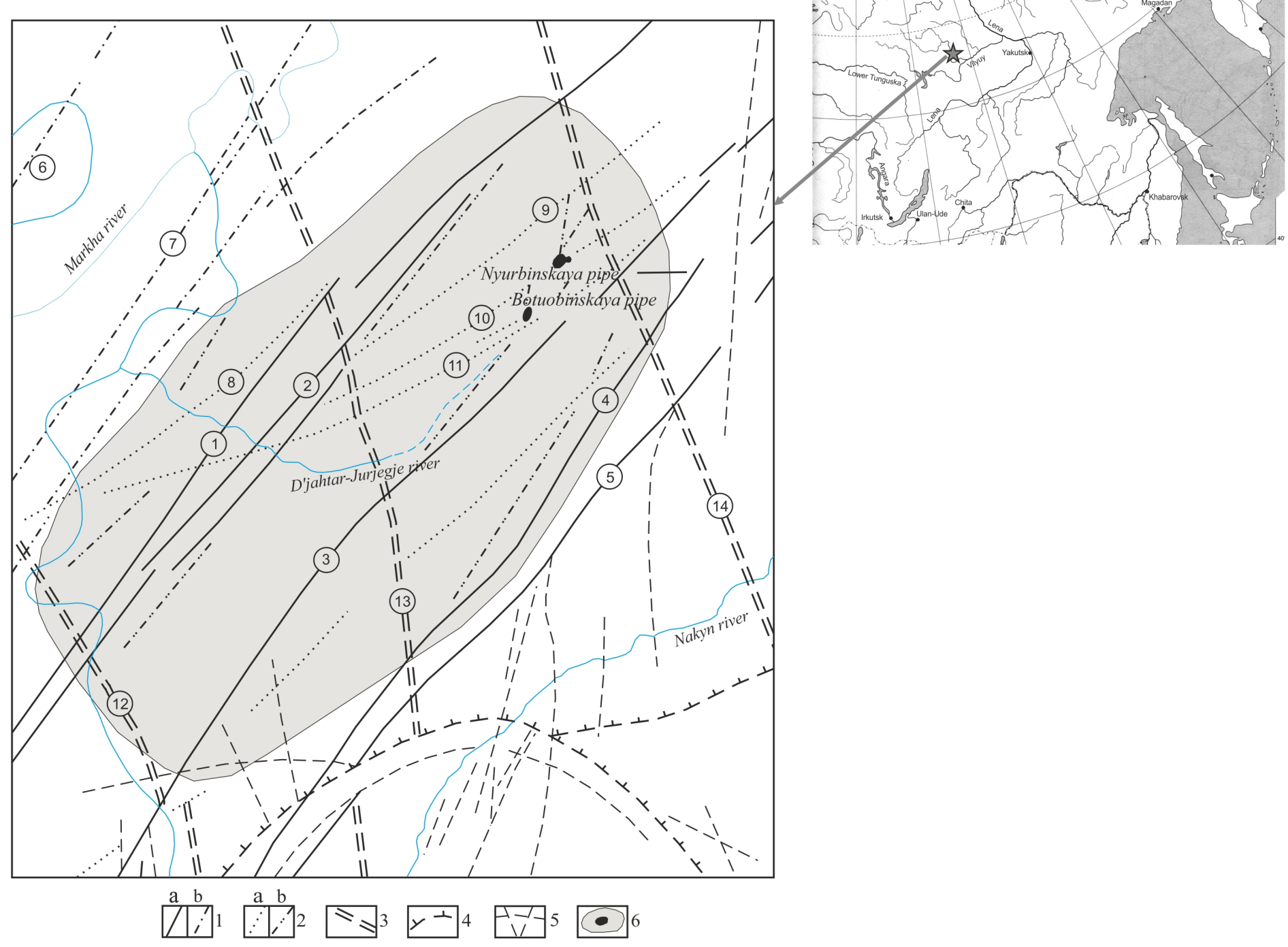

Fig. 1. Structural map of the Nakyn kimberlite field (after [Kharkiv et al., 1998]).

1-2 - faults of the Vilyui-Markha tectonic zone of the NE direction filled by the trapp dikes: 1 - of the first order: a - of central part of the zone (Liendokitsky, 2 - Badaransky, 3 - Yuzhnyi, 4-5 - Ust'-Nakynsky -I and -II), b - of its lateral branches (6 - Moroidon-Tyungsky, 7 - Khanninsky), 2 - of the third order: a - kimberlite controlling (8 - Ust'-Dyakhtarsky, 9 - Severny, 10 - Dyakhtarsky, 11 - Botuobinsky), b - supposed ore enclosing, cryptic, fragmentarily expressed in geophysical fields; 3 - faults of the Sredne-Markhinskaya tectonic zone of the NW direction of the second order determining the block-linear structure of the kimberlite field: 12 - Kurung-Yuryakhsky, 13 - Kyurgelyakhsky, 14 - Uzen-Uolbinsky); 4 - contours of subhorizontal trapp intrusions at different levels in sedimentary cover; 5 - circular and radial trapp apophyses (of dyke type); 6 - kimberlite pipes and supposed contour of the kimberlite field.

\section{Рис. 1. Структурная схема Накынского кимберлитового поля (по [Kharkiv et al., 1998]).}

1-2 - разломы Вилюйско-Мархинской тектонической зоны северо-восточного простирания, выполненные дайками траппов: 1 первого порядка: а - центральной части зоны (1 - Лиендокитский, 2 - Бадаранский, 3 - Южный, 4-5 - Усть-Накынский -I и -II), b - ее боковых ветвей (6 - Моройдон-Тюнгский, 7 - Ханнинский); 2 - третьего порядка: a - кимберлитоконтролирующие (8 Усть-Дьяхтарский, 9 - Северный, 10 - Дьяхтарский, 11 - Ботуобинский), b - предполагаемые рудовмещающие, скрытые, фрагментарно выраженные в геофизических полях; 3 - разломы Среднемархинской тектонической зоны северо-западного простирания второго порядка, определяющие линейно-блоковую структуру кимберлитового поля: (12 - Курунг-Юряхский, 13 - Кюргеляхский, 14 - Узен-Уолбинский); 4 - контуры субгоризонтальных интрузий траппов на разных уровнях в осадочном чехле; 5 кольцевые и радиальные апофизы траппов (даечного типа); 6 - кимберлитовые трубки и предполагаемый контур кимберлитового поля. 


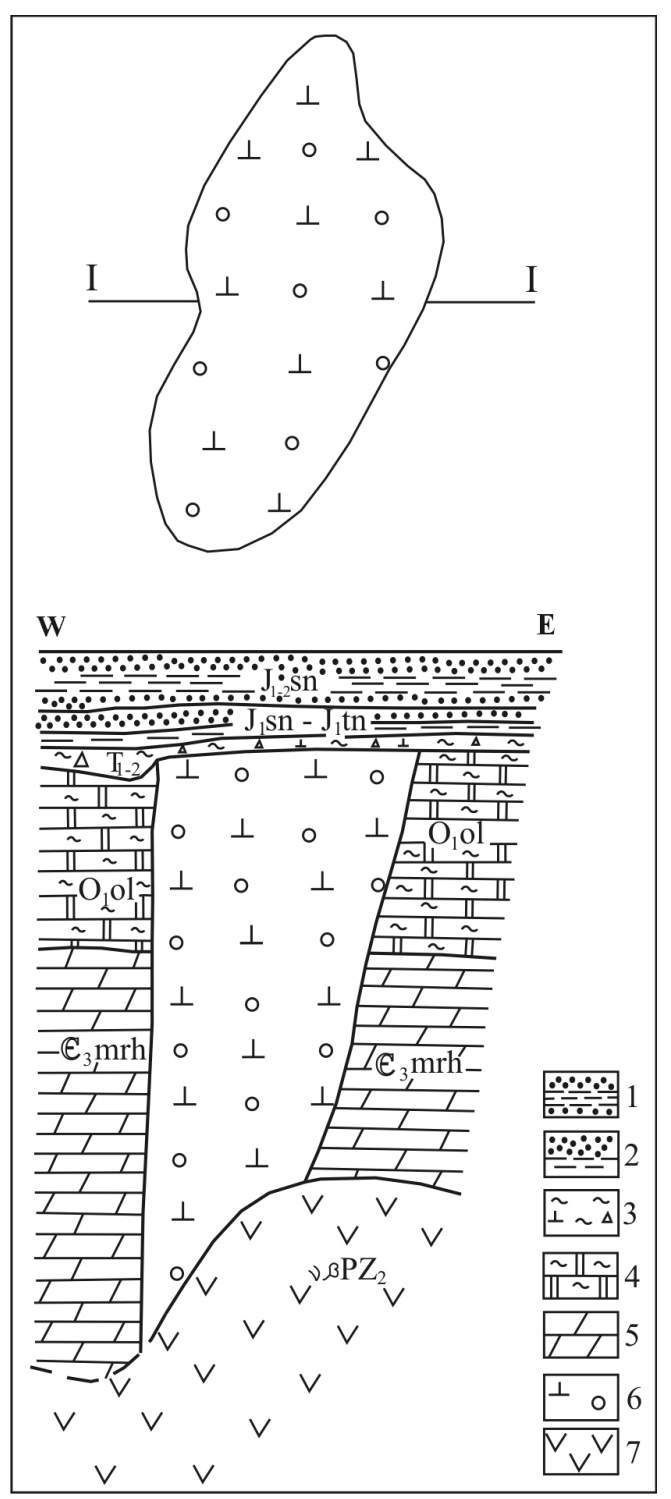

Fig. 2. Schematic plan and cross-section of the Nyurbinskaya kimberlite pipe (after [Kharkiv et al., 1998]).

1-3 - Mesozoic overlying rocks: 1 - argillites, aleurolites, sandstones of suntarskaya sequence, 2 - sandstones, aleurolites of tyungskaya and ukugutskaya sequences (non-segmented), 3 carbonate clays with detritus of dolomite, kimberlite, intensively weathered the Middle-Upper Triassic aleurolites; 4-5 - enclosing rocks: 4 - dolomites with intercalations of planopebbled conglomerates, limestones and aleurolites of oldonskaya sequence, 5 - limestones, marls, dolomites with intercalations of sandstones and argillites of markhinskaya sequence; 6 - autolith kimberlite breccias; 7 - dolerites.

Рис. 2. Схематический план и разрез кимберлитовой трубки Нюрбинская (по [Kharkiv et al., 1998]).

1-3 - перекрывающие породы мезозоя: 1 - аргиллиты, алевролиты, песчаники сунтарской свиты, 2 - песчаники, алевролиты тюнгской и укугутской свит (нерасчлененные), 3 карбонатные глины со щебнем доломитов, кимберлитов, интенсивно выветрелые алевролиты средне-верхнетриасовые; 4-5 - вмещающие породы: 4 - доломиты с прослоями плоскогалечных конгломератов, известняков и алевролитов олдондинской свиты, 5 - известняки, мергели, доломиты с прослоями песчаников и аргиллитов мархинской свиты; 6 - автолитовые кимберлитовые брекчии; 7 - долериты. magmatic phases of emplacement. But in both cases the exclusively compositional evolution of the kimberlite pipe formation is discussed without taking into account the dynamics of structure tectonic processes at the time of the kimberlite magma emplacement in the ore controlling zone.

Peculiarities of the faults structure determining the enclosing rocks structure are not enough studied. P.A. Ignatov on the basis of microstructural changes study in the enclosing rocks proposes the scheme [Ignatov et al., 2008], reflecting the kinematics of faults at the stage of the Nakyn field kimberlite bodies emplacement (Fig. 3). In his opinion the opening of the kimberlite bodies location was resulting from dextral motions along the Diagonalnyi fault and sinistral motions along the faults of the SE (Severnyi, Diyakhtarsky, Botuobinsky and Yuzhnyi) and SW (Vostochnyi a. o.) directions.

On the whole, the review of well-known works shows that scheme made by different authors characterizing the physical and structural characteristics of the Nyurbinskaya pipe are увязать между собой devoted to various aspects of the kimberlite body structure and enclosing sediments whicn are not reconciled. Similar "strictly specialized" approach to researches does not allow creating a single model of the pipe formation because dynamics of tectonic processes and sequence of compositional formation of the kimberlite pipe are inseparably linked with each other and it is their combination that determines the structure of the kimberlite bodies that we observe today. Therefore, the purpose of our work was to compare the formation succession and activation of the fault structure of area enclosing the pipe and sequence of compositional formation of the kimberlite body.

\section{INVESTIGATION TECHNIQUES}

To accomplish these ends we solved the problems of structural mapping of quarry field, reconstruction of tectonic stress fields and determination of the fault network formation mechanisms and analysis of the composition regularities of the Nyurbinskaya pipe different segments. Battery of methods used in various branches of geological knowledge was applied thereto.

The ore body composition and determination of different magmatic phases in the pipe volume were based both on detailed petrographic and mineralogical study of the kimberlite varieties and their contact relationships. The rocks were studied through the transparent thin sections and regrinding of piece of ore samples to calculate the main rock components and study under a binocular loupe in the translucent and reflected light. On the basis of the petrographic characteristics (contrasting differences in the rock composition, the 


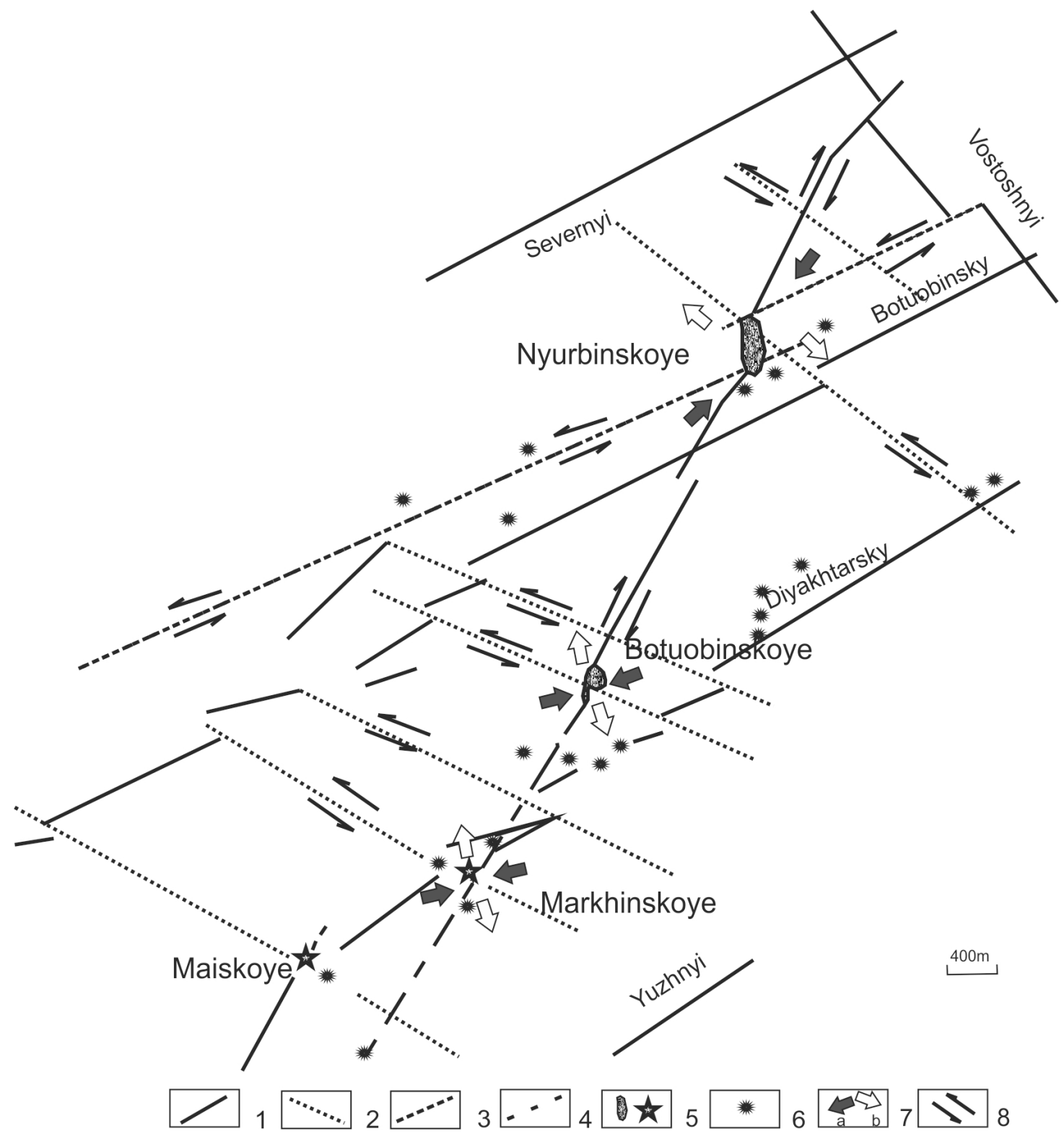

Fig. 3. Tectonodynamic sketch map of central part of the Nakyn field [Ignatov et al., 2008].

1 - dikes of trapp of the Vilyui-Markha fault zone; 2 - transcurrent kimberlite controlling strike-slip faults; 3 - longitudinal kimberlite controlling sinistral displacements; 4 - the Diagonalnyi ore-enclosing dextral displacement; 5 - kimberlite bodies (their centres are shown for dikes); 6 - eruptive breccias of alkaline basites; 7 - supposed position of axes of compression (a) and extention (b) projective on horizontal plane; 8 - supposed displacements of the fault sides.

Рис. 3. Тектоно-динамическая схема центральной части Накынского поля [Ignatov et al., 2008].

1 - дайки траппов Вилюйско-Мархинской зоны разломов; 2 - поперечные кимберлитоконтролирующие сдвиги; 3 - продольные кимберлитоконтролирующие левые сдвиги; 4 - Диагональный рудовмещающий правый сдвиг; 5 - кимберлитовые тела (для даек показаны их центры); 6 - эруптивные брекчии щелочных базитов; 7 - предполагаемое положение осей сжатия (а) и растяжения (b) в проекции на горизонтальную плоскость; 8 - предполагаемое смещение берегов разрывов.

presence of fragments and kimberlite autoliths of earlier phases of emplacement etc.) the main kimberlite varieties composing the pipe were distinguished as well as the sequence of the magmatic phase intrusion. In the absence of autoliths or fragments the character of contact zones between the kimberlite varieties was studied both in field conditions and in lump of ore samples. Other criteria that allow distinguishing different phases of kimberlites were industrial indicators (total diamond, the ratio of screen classes diamond). Earlier authors works for the multiphase Yubileinaya pipe, as well as study of the industrial characteristics of the different types of kimberlites in the Nyurbinskaya and Komsomolskaya pipes suggest that these indica- 
tors in the kimberlite various phases significantly differ. Study of industrial characteristics was performed with statistical methods based on the results of field prospecting and data obtained from industrial processing of units composed of different petrographic types of kimberlites. Distribution of different magmatic phases of kimberlitesin the pipe volume was established by the method of direct geological observations (mapping) and on the basis of study of core materials of prospecting holes with identification of differenttype kimberlites using the reference petrographic collection of kimberlites which was created earlier. Spatial characteristics of the earliest phases of magmatic activity which were partially or completely destroyed by subsequent portions of kimberlite melt were empirically determined by the quantitative analysis of these phases fragments abundance in the cross sections of the pipe modern outline.

Geologo-structural elements of the Nyurbinskaya pipe location structure were studied using field and experimental tectonophysical methods. The first of them constitutes a set of methodological developments and techniques aimed at the field study of fault zones, mapping of major elements of their internal structure and reconstruction of tectonic stress fields. The basis for the implementation of these methods are the observation points created during field works within which the complex of similar tectonophysical and geological-structural measurements is performed (total of 488 points). Standard point of observations in the Nyurbinskaya pipe quarry was a segment of wall quarry (at a certain horizon) with length from 5 to $20 \mathrm{~m}$.

Procedure of observations is described in detail in the work [Gladkov et al., 2008]. It included the following operations: point location on the plan, detailed study of fracturing and fault network of different ranks. Statistical measurement of 100 fractures within the arbitrarily chosen site with the obligatory indication of their genetic variety was made. In the process of measuring a particular attention was given to the detection of fractures that occurred during blasting operations and for this reason they were not included in measurement. In the case of slickensides their orientations and morphology were documented. In addition to faults other structural forms (if available) such as folds, boudines, linearity etc. were described.

Information collected in this way was presented in the form of the table. It was further processed and analyzed using the known software products as well as the original development of the laboratory of tectonophysics - the software complex STRUCTURE meant for plotting, processing and analysis of structural diagrams by the fractures and faults measurements.

The obtained data formed the basis for tectonic scheme of the Nyurbinskaya pipe location and allowed to reconstruct the tectonic stresses fields for different stages of the development of structure enclosing kimberlite body.

Optical simulation method was used for experimental check of the findings. This method is traditionally applied to study the specificity of the stress field redistribution in the neighborhood of faults and is a tool for testing the various hypotheses of the fault and block structure evolution of the upper part of the earth's crust. Its main feature is the specificity of stress state when the main normal stresses lie in the model horizontal plane that is consistent with the dominant values of stress ratio in the earth's crust [Kropotkin et al., 1987; Leonov, 1995].

Studies were carried out on the equipment (polariscope-polarimeter PKS-250) of Laboratory of tectonophysics of the Institute of Earth's crust. Gelatinous gel, jelly properties and conditions similarity of which are described in details in the work of D.N. Osokina [Osoki$n a$, 1963] were used for modelling. All models were prepared by the same methodology described in the work [Cheremnykh, 2010]. After calibration the experimental scheme with the fault network was transfered to the model. Thus, all characteristics of fault and block structure of the earth's crust were took into account. All faults were plot in the form of vertical cuts through the model thickness with lubrication of their surfaces by water. In the course of the experiment the distribution pattern of colours (isochromes and isoclines) in models was fixed by digital camera for subsequent processing of the obtained pictures.

A comprehensive analysis of the physical, geologostructural and experimental data collected using the given methods allowed in the total to obtain a qualitatively new structural-compositional model of the Nyurbinskaya pipe.

\section{FINDINGS AND THEIR INTERPRETATION}

\subsection{PECULIARITIES OF THE NYURBINSKAYA PIPE COMPOSITIONAL STRUCTURE}

The data obtained allow concluding that the compositional structure of the Nyurbinskaya pipe is determined by the presence of at least four phases of kimberlites, which formed different forms of geological bodies within the present ore body contour (Fig. 4).

The first phase is represented by the micaceous porphyric kimberlites (PK) which characterized by medium- and magnophyric structure, considerably micaceous groundmass and high degree of deuteric alterations as well as by lower content of both crustal and mantle xenoliths. Porphyric kimberlites occur in a modern cut in prior to ore dikes as well as in the form of fragments or autoliths in kimberlites of subsequent magmatic phases. Unlike most kimberlite deposits of 


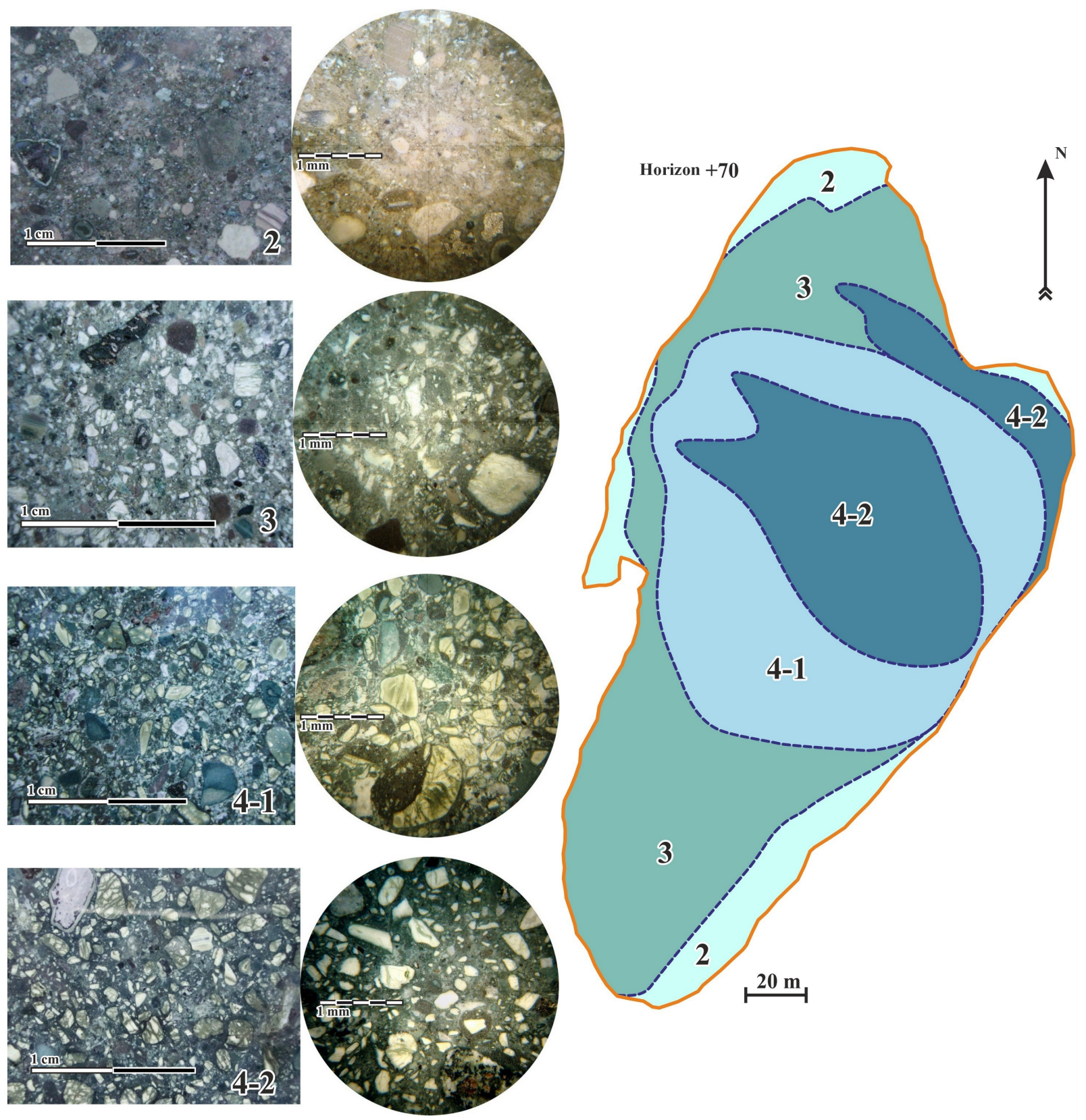

Fig. 4. Compositional structure of the Nyurbinskaya pipe. Explanations are in the text.

Рис. 4. Вещественное строение трубки Нюрбинская. Пояснения в тексте.

the Yakutian diamondiferous province the porphyric kimberlites in the Nyurbinskaya pipe are of subordinated state and do not form the bulky geological bodies within the pipe. The autoliths and fragment of porphyric kimberlite content increases to the northeast from the pipe center tracing the original position of dike-shaped body of porphyric kimberlites. The maximum number of micaceous porphyric kimberlites fragments occurs in the central part of the present-day pipe contour closer to its western contact. Distribution and size characteristics of fragment suggest that kimberlite of the first phase composed here a stock-like body. Its boundaries are distinguished by results of studying the content and size changes of the PK fragments in later magmatic phases.

The second magmatic phase is presented by eruptive kimberlite breccias. They characterized by breccia, psephitic structure due to large xenoliths of various sedimentary rocks (40-60\%) and fragments of porphyric kimberlites (up to $20 \%$ ). As opposite to porphyric kimberlites a significant quantity of granulites and garnet peridotites xenoliths there is here. The matrix is composed of gypsum-carbonate with fragmented material of sedimentary rocks. A large variety of sedi- 
mentary rocks xenoliths predominantly of rounded forms without chilling traces suggest that the above breccias are independent magmatic phases. In case of near-contact contamination the xenoliths of enclosing rocks are usually similar and angular, often with zones of secondary hydrothermal alterations [Sablukov et al., 2008]. In the modern cut the bodies fragments composed of eruptive breccias are preserved only in the pipe near-contact parts. Within the main body composed of the later phases their boundaries are recognized by "shadow" contact zones contouring the areas with increased content of the sedimentary rock xenoliths and kimberlite breccias fragments. Overall, our data allows identification of small bodies of eruptive kimberlite breccias of the second phase within the south-eastern and north-western flanks of the pipe present-day contour (Fig. 4, kimberlite 2).

Magmatic formations of the third phase are presented by autolith kimberlite breccias (AKB). The rocks are characterized by brecccia autolith texture due to large, often angular, pseudomorphs after olivine (clastoporphyric, protoclastic structure) as well as autoliths and fragments of micaceous porphyric kimberlites. Fragments of sedimentary rocks and xenotiths of granulites are less common. Autolith kimberlite breccias of the third phase compose almost entirely the southeastern column-like body (Fig. 4, kimberlite 3). It should be noted that autolith breccias of the pipe southeastern part are characterized by a much smaller volume of xenogenic material unlike previous explosive phase even in near-contact zones with enclosing rocks. Another characteristic of the AKB of the pipe southern part is extremely uneven content of autoliths (from 0 to $15 \%$ ); any regularity in their distribution is not found.

The rocks of the fourth phase are also represented by autolith breccias charaterized by breccia, autolith texture, deuteroporphyric structure, high content of pseudomorphs after olivine I (40-45\%) and autoliths (30-35\%). Unlike the AKB of the third phase the kim- berlites of final magmatic stage contain pseudomorphs after olivine predominantly of rounded, rounded-oval form. The AKB of the fourth phase show abnormally high content both crustal and mantle inclusions, their content amounts $20-25 \%$ of the rock total volume. In addition, the above AKB show the presence of large fragments (up to $60 \mathrm{sm}$ ) of kimberlites of previous emplacement phases. Rocks of the four phase form the stock-like geological body in the diatreme center and compose the north-eastern segment of the pipe present-day cut (Fig. 4, kimberlites 4-1 and 4-2). Within the stock two petrographic varieties of autolith breccias are recognized, they differ from each other in quantity of pseudomorphs after olivine and content of the mantle and crustal rocks inclusions. The latter suggests either magmatic differentiation during the kimberlite melt intrusion or the stock pulsating formation. The contact zone between the kimberlite breccias of southeastern and north-western flanks shows gradual transition with formation of the hybrid rocks with thickness of up to 3-5 m.

Summarizing the ore bodies forming the sequence composing the Nyurbinskaya pipe diatreme the following conclusions can be drawn: 1) the first significant volumes of the kimberlite gas-saturated fluid-melt were intruded within southern flank of the pipe present-day contour; 2) subsequent magmatic phases formed initially the southeastern, eastern contour of the diatreme, then the western, north-western one; 3 ) autolith kimberlite breccias of final stage of the pipe formation were intruded in central part of the pipe northern flank in the already formed the main diatreme contour, though orientation of its long axis does not coincide with that of the ore bodies of the earlier phases. In addition, the kimberlites of each of these magmatic phases have their specific characteristics of the diamond potential (total diamond content, ratio of screen classes, crystals quality). The Table lists the main parameters of the diamond potential for the most

\section{Basic industrial indices of the different phase kimberlites from different stages of the Nyurbinskaya pipe formation}

Основные промышленные показатели в разнофазных кимберлитах различных этапов становления трубки Нюрбинская

\begin{tabular}{|c|c|c|c|c|}
\hline $\begin{array}{l}\text { Indices of diamond } \\
\text { potential }\end{array}$ & $\begin{array}{l}\text { Screen } \\
\text { classes }\end{array}$ & $\begin{array}{l}\text { Kimberlite breccias of the } 2 \text { stage } \\
\text { with xenogenic material (content } \\
\text { not more than } 40 \% \text { ) }\end{array}$ & $\begin{array}{l}\text { Autolith kimberlite breccias } \\
\text { of the } 3 \text { stage (southern } \\
\text { flank of the pipe) }\end{array}$ & $\begin{array}{l}\text { Autolith kimberlite breccias of } \\
\text { the } 4 \text { stage (central and north- } \\
\text { eastern part of the pipe) }\end{array}$ \\
\hline $\begin{array}{l}\text { Variations of total } \\
\text { content (in reference } \\
\text { units) }\end{array}$ & $\begin{array}{l}+0.5 \\
-4+1\end{array}$ & $\begin{array}{l}15-50 \\
10-47\end{array}$ & $\begin{array}{l}42-70 \\
24-46\end{array}$ & $\begin{array}{l}63-200 \\
48-160\end{array}$ \\
\hline $\begin{array}{l}\text { Content by classes } \\
\text { in } \% \text { (average) }\end{array}$ & $\begin{array}{l}-1+0.5 \\
-2+1 \\
-4+2\end{array}$ & $\begin{array}{l}43.32 \\
40.27 \\
16.41\end{array}$ & $\begin{array}{l}23.04 \\
37.93 \\
39.03\end{array}$ & $\begin{array}{l}30.12 \\
50.09 \\
19.79\end{array}$ \\
\hline $\begin{array}{l}\text { Number of samples } \\
\text { with stones of }+4 \\
\text { classes }(\%)\end{array}$ & & 21 & 37 & 41 \\
\hline
\end{tabular}




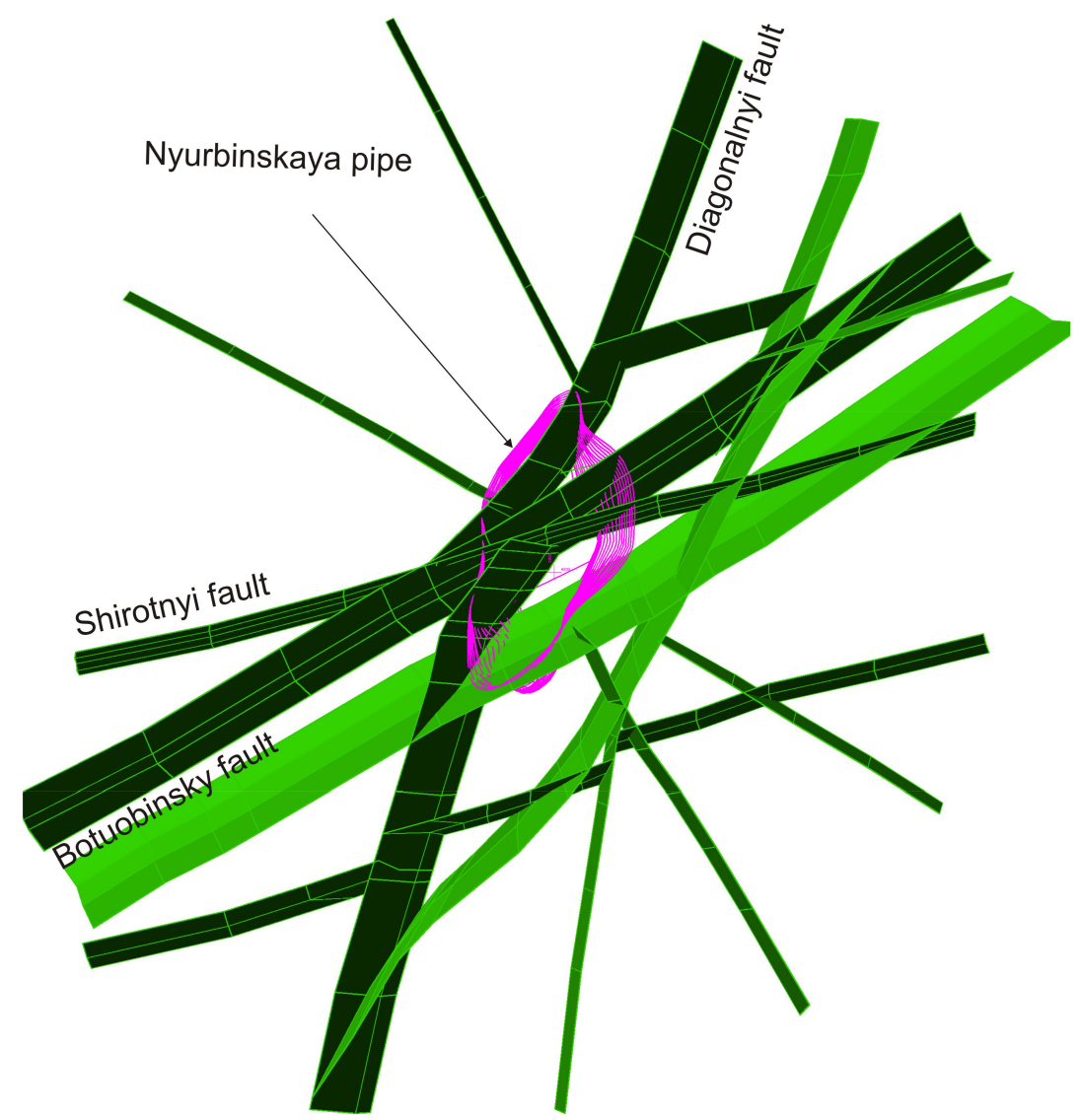

| Fig. 5. 3D scheme of the fault and block structure of the Nyurbinskaya pipe location (top view).

| Рис. 5. Трехмерная схема разломно-блокового строения участка локализации трубки Нюрбинская (вид сверху).

common types of kimberlites within the Nyurbinskaya pipe - eruptive kimberlite breccias of the second phase and autolith kimberlite breccias of the third and four phases. Characteristics of the diamond potential for porphyric kimberlites are not given because their small volume.

From the assumption that there are no evidence of sharp, tearing, injected contacts between geological bodies of different magmatic phases but the thick zones of mixed, hybrid rocks occur it is believed that the time intervals between the melt portions emplacements were minor. In other words, each subsequent portion of kimberlite fluid-melt was intruded in not yet completely consolidated kimberlites of previous phase. According to preliminary data, one can see a similar picture of the emplacement of different phases of kimberlites in a new high-diamondiferous kimberlite body the Maiskaya pipe [Tolstov et al., 2009].

\subsection{PeCUliarities of teCtONIC STRUCTURE OF THE NYURBINSKAYA KIMBERLITE PIPE LOCATION}

The result of survey work of the quarry slopes at different levels showed that subvertical (dip angles of $60^{\circ}$ and more) and subhorizontal (dip angles $<30^{\circ}$ ) faults and tectonic fractures play a decisive role in tectonic structure of the rock mass. Inclined faults of different rank are less common.

Mapping of faults within the mine working was performed by fixing their outputs at different horizons and their tracing in the quarry slopes. The observations allowed compiling a detailed scheme of fault and block structure of the Nyurbinskaya pipe location (Fig. 5). According to the scheme, the kimberlite body is confined to the regional fault junction of the NE (Botuobinsky), ENE (Shyrotnyi) and NNE (Diagonalnyi) trends. Each of the above faults consists of a series of subparallel different in scale dislocations.

The Botuobinsky fault represents a graben not less than $200 \mathrm{~m}$ width bounded by zones of high fracturing, crushing and grinding, inclined in each other (dip azimuth $325^{\circ}$ and $145^{\circ}$, respectively) at the angles of $70-85^{\circ}$. This structure is well identified in benches of eastern pit wall (Fig. 6). The thickness of dislocations bounded the graben slightly differ according to different levels reaching 10 meters or more. Amplitudes of normal faults along the graben boundaries are of few meters. In addition, the internal structure of 


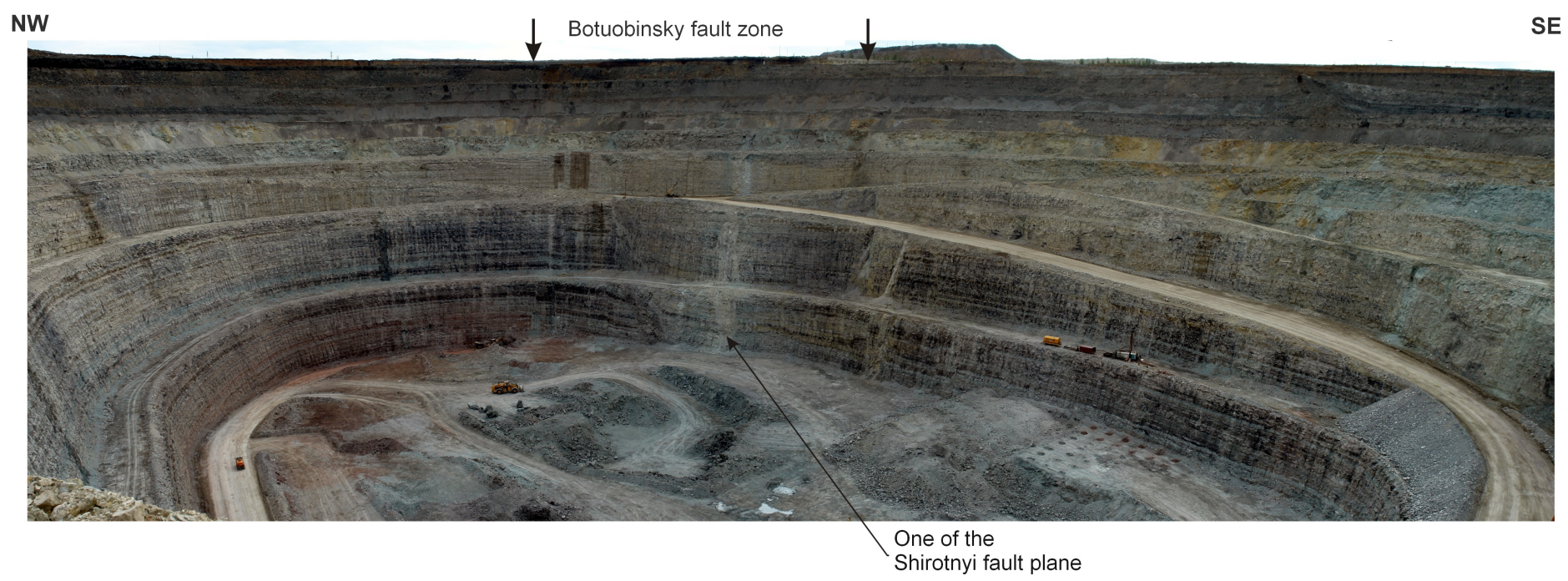

Fig. 6. Outcrops of the Botuobinsky fault zone and one of the Shirotnyi fault plane in the eastern pit wall of the Nyurbinskaya pipe quarry.

Рис. 6. Выходы нарушений зоны Ботуобинского разлома и одного из сместителей Широтного разлома в восточном борту карьера трубки Нюрбинская.

graben and its flanks is complicated by multiple small dislocations and large fractures with displacements of amplitudes from centimeters to tens of centimeters.

The Shirotnyi fault is characterized by the ENE direction $\left(70-75^{\circ}\right)$ and represents a series of subparallel brecciated zones, zones of crush and high rock fracturing. Zone of large-block breccias of about $10 \mathrm{~m}$ thickness is noted in central part of the eastern and western quarry slope (see Fig. 5, Fig, 7, A). Another zone of crush and brecciation of this trend about $7 \mathrm{~m}$ thickness is tracing within the quarry slopes near the pipe southern end (Fig. 5, Fig. 7, B). And, finally, the zone segment of high fracturing of the ENE trend is recorded in eastern pit wall near northern contact of kimberlite body (Fig. 5). The dip to the SSE at angles of $70-85^{\circ}$ is typical of most dislocations of this orientation.

The NNE Diagonalnyi fault is mainly presented by zone of high fracturing of the first tens of meters width, sometimes with elements of crushing and grinding of the rocks. The last case is usually occurs near contacts with ore body. Series of kimberlite dikes of from 0.1 to $0.5 \mathrm{~m}$ thickness (Fig. 8) is fixed in enclosing rocks of northern and southern pit walls. The Diagonalnyi fault represents two subparallel contiguous dislocations in enclosing rocks in the south-western diatreme exocontact (see Fig. 5).

The materials obtained allowed to identify the formation stages of fault structure of the studied area. Observations of dislocations displacements along faults of different ranks, position of folded structures; in addition, the fracture statistical measurements were pro- cessed and axes positions of principal normal stresses were reconstructed.

\subsubsection{Fault displacements}

Predominantly vertical displacements (normal and reverse faults) were recorded for subvertical and inclined dislocations of different trends. This is due to the feature of the geological section structure: there are no markers of the horizontal displacements traces. Rosediagrams (Fig. 9, 1, A, B) suggest that a large part of the vertical fault displacements was fixed on the faults of NE and ENE trends. Significantly fewer their amount is related to faults of other orientations. The recorded faults with vertical displacements are often characterized by both normal and reverse fault displacements along faults of the same trend. Quite common is the situation when differently directed displacements occur along series of contigeous faults, with opposing dip at angles of $55-80^{\circ}$.

Characteristics of such structural forms combining the normal and reverse fault displacements allowed in some cases to reconstruct the sequence of their formation. For example, at first, as a result of extension the wedge-type blocks of the rock subsidence forming in the whole a graben-like structure (Fig. 10, 1) occurred along the ENE fractures (Fig. 10). Then, along the previous fractures under compression conditions the reverse faults displacements took place at the expense of "extrusion" of subsided blocks and crumpling of their single elements with gentle anticlines formation (Fig. 10, 2). 
A

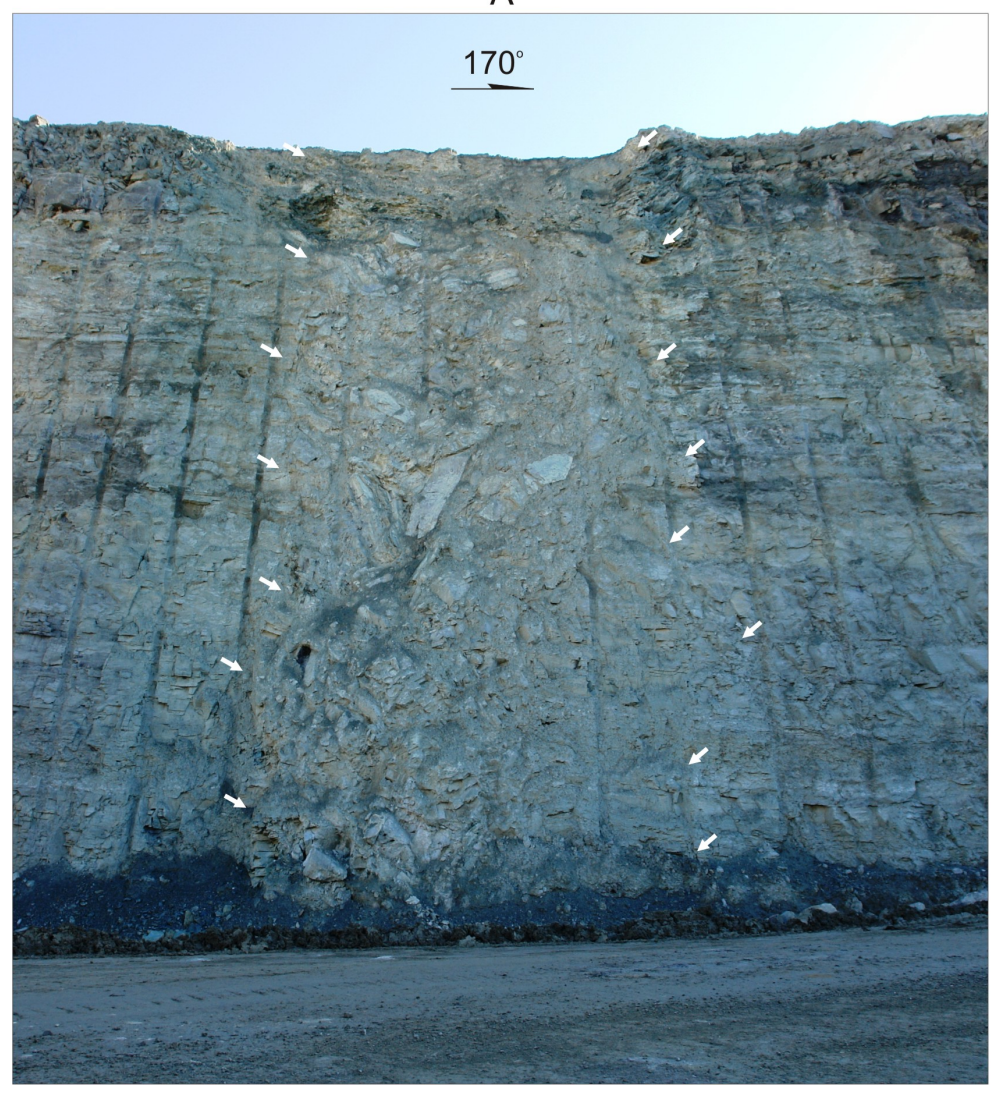

B

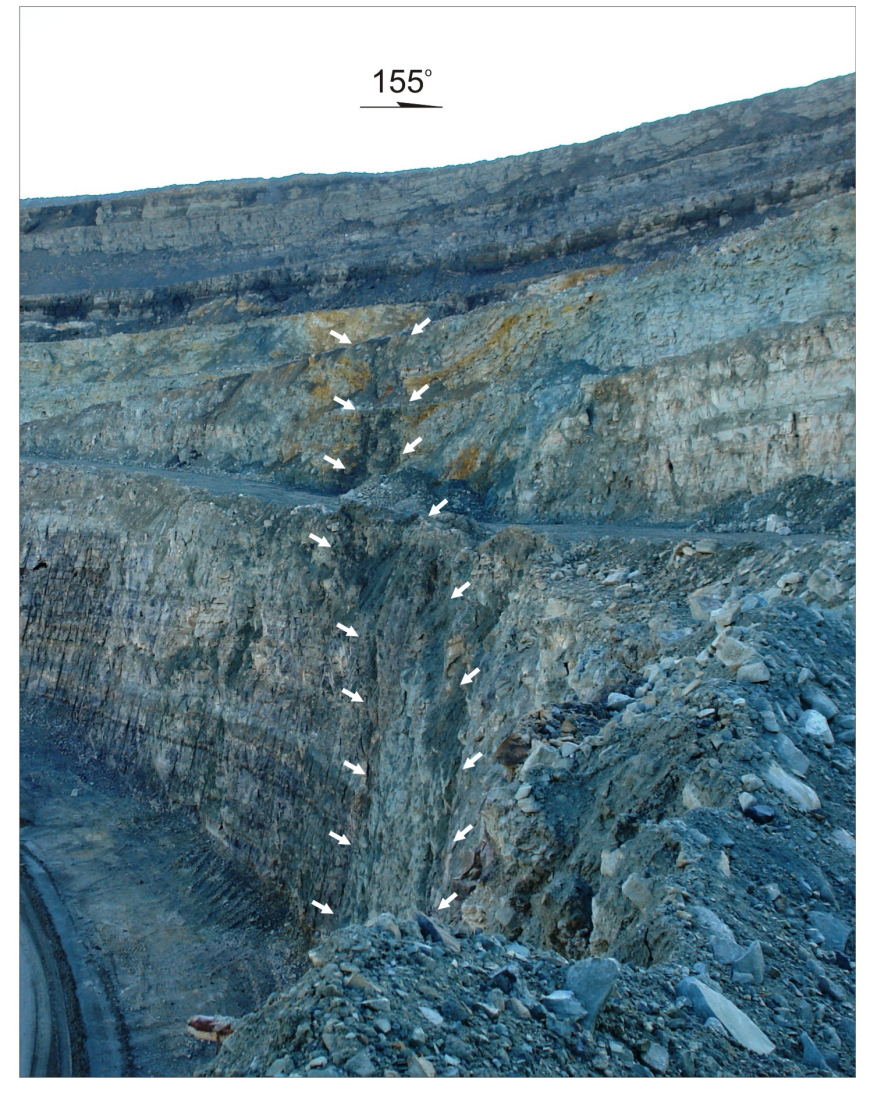

Fig. 7. Outcrops of the Shirotnyi fault.

$A$ - zone of large-block breccias of central part of eastern pit wall of the quarry; $B$ - zone of crushing and brecciation in southern slopes of the quarry.

Рис. 7. Выходы нарушений Широтного разлома.

$A$ - зона крупноглыбовых брекчий центральной части восточного борта карьера; $B$ - зона дробления и брекчирования в южных откосах карьера.

\subsubsection{Slickensides}

It should be mentioned that slickensides were chiefly recorded near the fault planes. Therefore, the points at which the structural elements were observed were not numerous. For the most part, the slickensides occurred on calcite, gypsum and, sometimes, serpentinite films and veinlets filling the fractures. They are, on the whole, satisfactorily preserved, however, the signs indicating the direction of displacements were rare, that, coupled with a small number of slickensides not allowed to collect any meaningful data for use the kinematic methods to restore the tectonic stress fields.

Unlike the fault displacements the slickensides allowed to register the traces of both subvertical and strike-slip motions on the faults. Rose-diagram (see Fig. 9, 1, C) constructed for faults with dip directed slickensides is more complex that those obtained for the fault displacements (Fig. 9, 1, A, B). It suggests that besides the NE and ENE faults the normal and reverse displacements took also place along faults of submeridional and NW trends. Diagram of faults with subhorizontally slickensides (Fig 9, 1, C) suggests that the greatest occurrence of strike-slip displacement traces is recorded within the NE and NNE faults. The slickensides pointing to strike-slip displacements were also registered on the planes of the NW, WNW, NNW and ENE trends.

Overall, the data obtained (Fig. 9, 1, E) suggest that the displacements or their traces of significantly different types (from horizontal to vertical) were registered along the same orientations and, as has been shown above, some of them were of alternating chacacter. Based upon the known patterns of the fault formation of different kinematics in a single tectonic stress field [Seminsky et al., 2005], the observed assemblage of faults (Fig. 9, 1, E) are "decomposable" into 4 paragenetic associations. Each of them includes two conjugated strike-slip faults as well as the normal and reverse faults (Fig. 9, 2). 


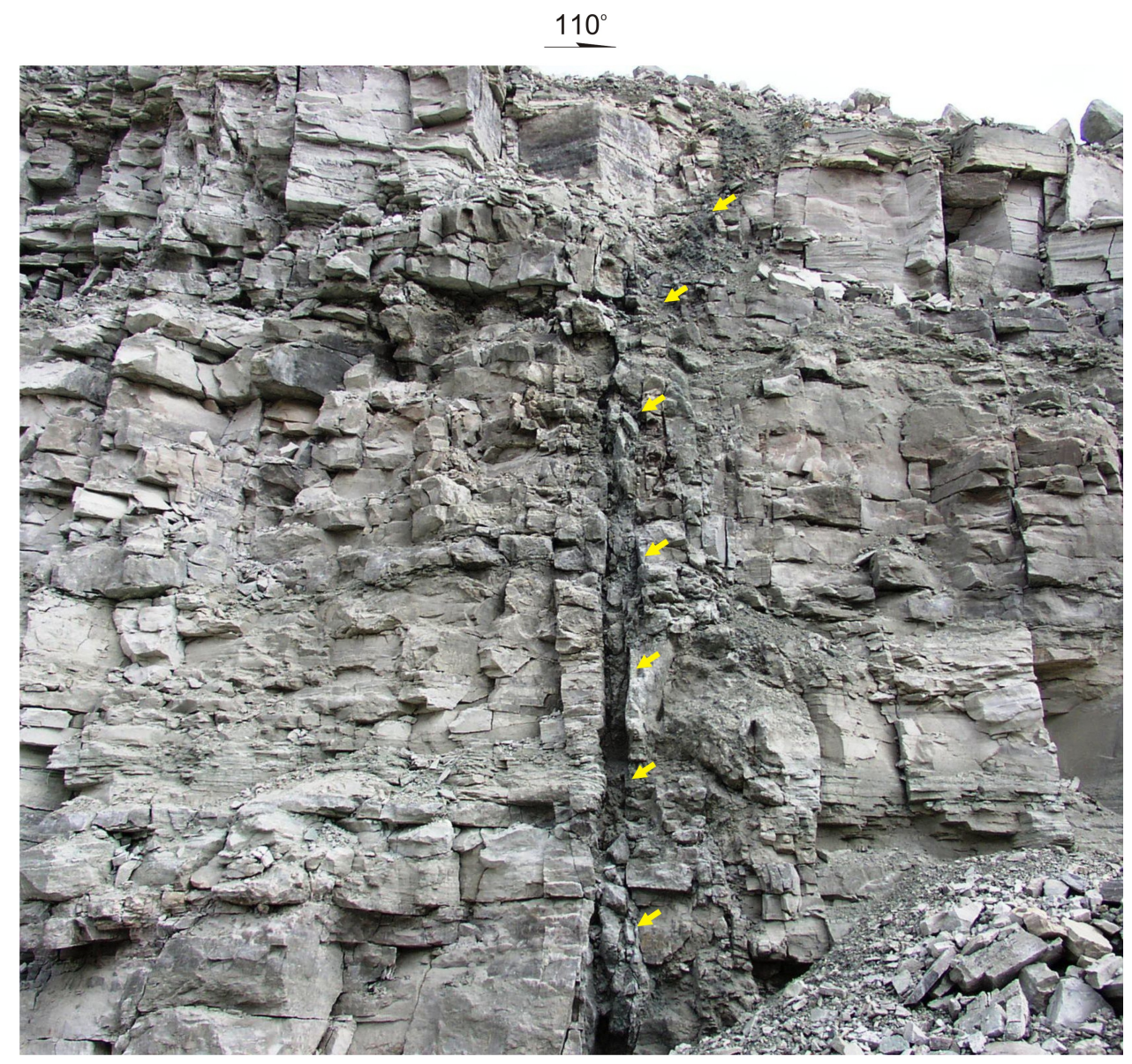

Fig. 8. Fragment of the Diagonalnyi fault zone (quarry's southern slopes). Yellow arrows underline the kimberlite dike of 0.15-0.25 m thickness.

Рис. 8. Фрагмент зоны Диагонального разлома (южные откосы карьера). Желтыми стрелками подчеркнута дайка кимберлитов мощностью 0.15-0.25 м.

\subsubsection{Results of processing of statistical measurements of tectonic fracturing}

We managed to make statistical measurements of tectonic fracturing (90-100 fractures) by virtue of objective reasons (mine safety requirements) in four points, located within the kimberlite body (site 0705), in enclosing (site 0905) and overlapping (site 0318) sediments and near their contact (site 1002), respectively. Their analysis was carried out using a set of methodological techniques; its implementation is illustrated by the example of site 0705 , located in the ore body in close proximity to the Diagonalnyi fault plane.

The diagrams show the presence of characteristic pictures - belts of fracturing [Gladkov, Seminsky, 1999; Danilovich, 1961] of two types (Fig. 11). The first of them are formed by maxima located around the periphery of great circle (belt A in Fig. 11,2) and correspond to the strike-slip displacement. The latter represent a chain of maxima along the arc of the great circle, passing through the diagram central part (belt $\mathrm{C}$ in
Fig. 11, 2). With regard to the site 0705 (Fig. 11) one can say that both belts are associated with displacemets in the Diagonalnyi fault zone (maximum with dip azimuth $285^{\circ}, \angle 78^{\circ}$ is the point of the belts intersection and corresponds to the fault plane). This suggests that at various stages of development the vertical displacements occurred on the mentioned fault in one case and the horizontal displacements took place in another one.

Method of P.N. Nikolaeyv [Nikolayev, 1977] was used for identification of the conjugated systems of fractures. The square diagrams (Fig. 11,1) whereon the asymmetric maxima characterized by opposite directions of preferential scattering recognized as conjugate ones were analyzed [Nikolayev, 1977]. Further reconstructions of the principal normal stresses axes were made using the procedures cited in the monograph of M.V. Gsovsky [Gsovsky, 1975] (see Fig. 12).

More than one alternate solutions for the position of the principal normal stresses axes were obtained in three sites. For example, in the site 0705 two solutions 
(1)
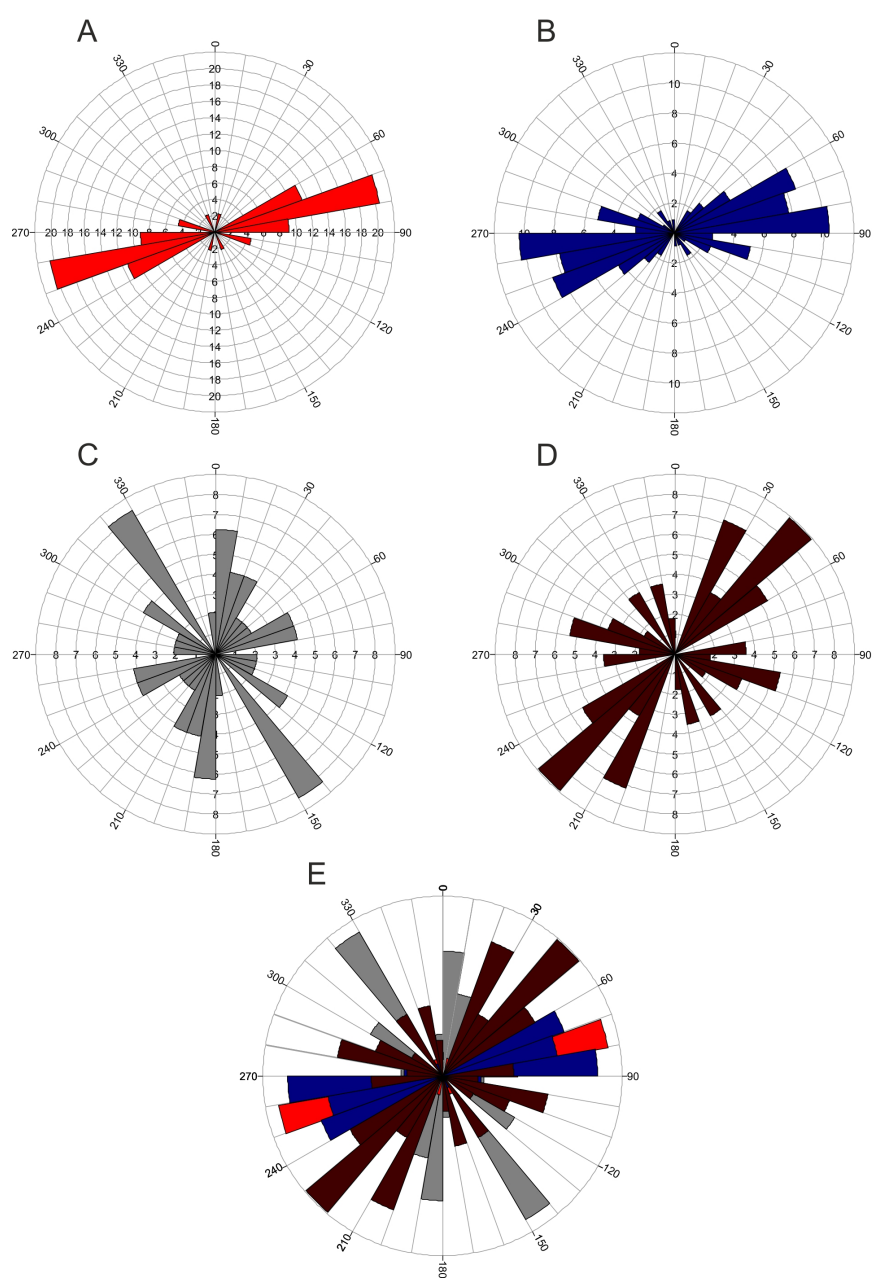

A
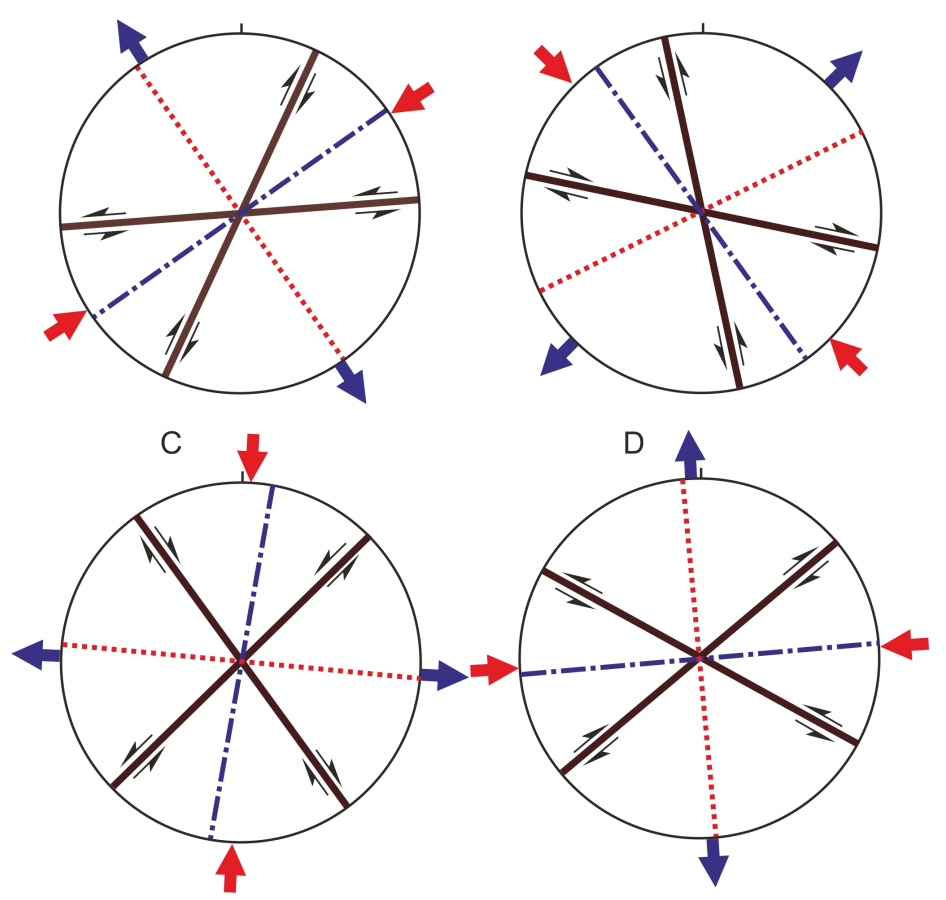

B

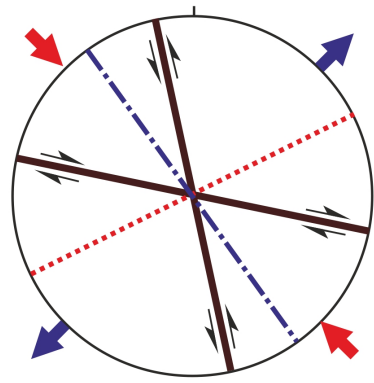

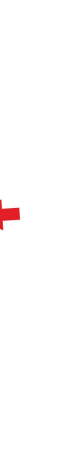

Fig. 9. Rose-diagrams of subvertical faults with traces of displacements (1) and diagrams of supposed parageneses of subvertical faults formed in different fields of tectonic stresses (2).

1 - diagrams: A - faults with reverse displacements, B - faults with strike-slip displacements, C - faults with dip slickensides, D - faults with strike slickensides, E - cumulative diagram for faults with displacement traces; 2 - supposed parageneses of subvertical faults formed in the stress fields: A - NE compression, NW extension, B - NW compression, NE extension, C - submeridional compression, sublatitudinal extension, $\mathrm{D}$ - sublatitudinal compression, submeridional extension.

Рис. 9. Роза-диаграммы субвертикальных разрывов со следами перемещений (1) и диаграммы предполагаемых парагенезисов субвертикальных дизъюнктивов, сформированных в различных полях тектонических напряжений (2).

1 - диаграммы: A - разрывы со взбросовыми смещениями, В - разрывы со сбросовыми смещениями, С - разрывы со штрихами по падению, D - разрывы со штрихами по простиранию, Е - сводная диаграмма для разрывов со следами перемещений; 2 - предполагаемые парагенезисы субвертикальных разрывов, сформированных в поле напряжений: А - северо-восточного сжатия, северо-западного растяжения, В - северо-западного сжатия, северо-восточного растяжения, С - субмеридионального сжатия, субширотного растяжения, D - субширотного сжатия, субмеридионального растяжения.

conforming to the strike-slip solutions and two solutions conforming to the reverse displacements are restored. In the first case (Fig. 12,1) the compression axis is orientied north-eastward and the extention axis is orientied north-westward. The second solution is opposite to the first: northwest compression and northeast extention (Fig. 12,2). And in both cases, the faults appropriate to the Diagonalnyi fault plane is one of the conjugated system. The finding suggests that within this fault zone there were strike-slip displacements at different stages of development directly opposite in sign. Solution appropriate to the north-eastern compression (Fig. 12,3) is interpreted by us as a special case of the strike-slip field (Fig. 12,1) meeting the formation of compression structures (thrusts and reverse faults of the NW trend) in the strike-slip paragenesis of 


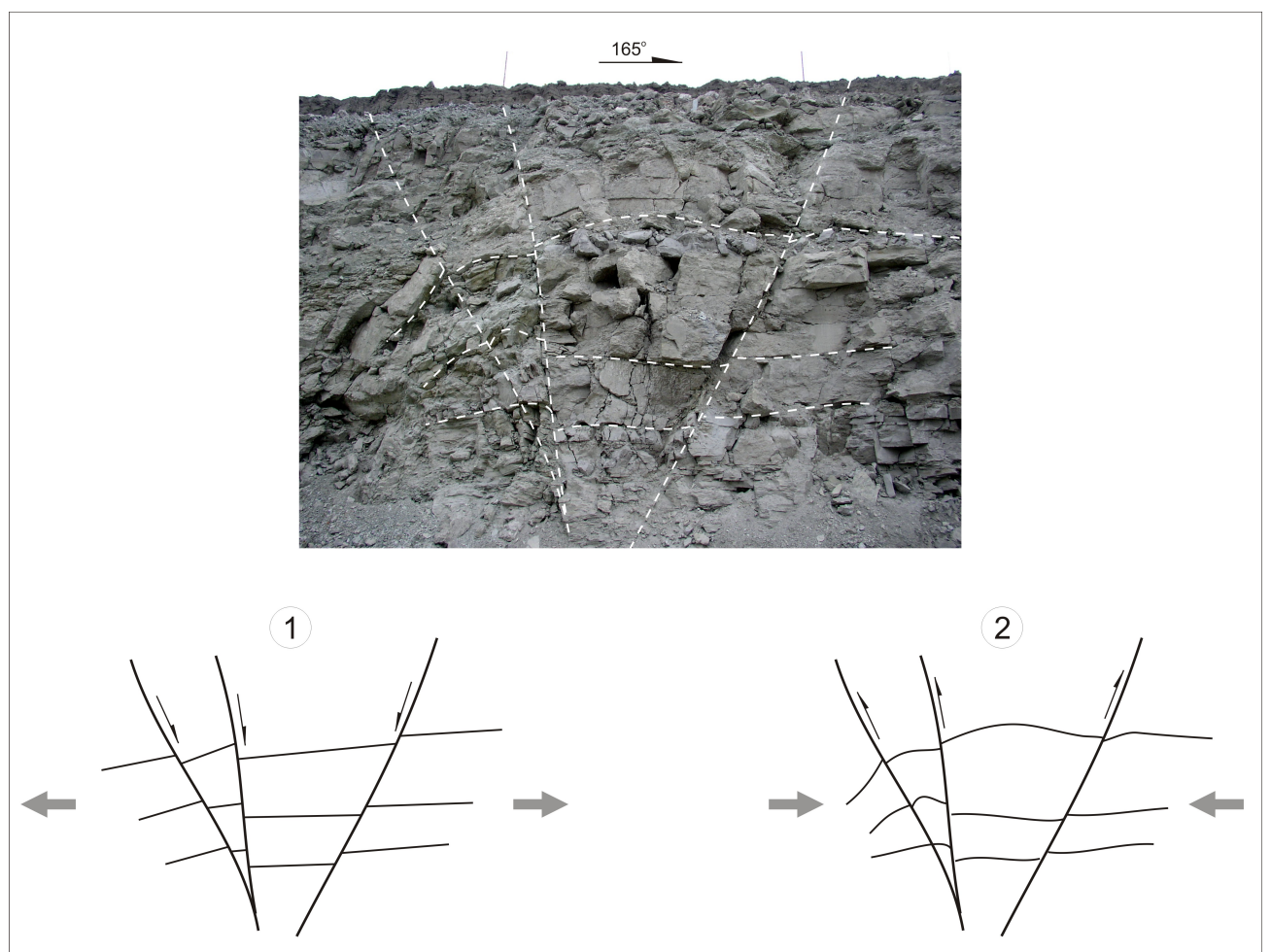

Fig. 10. Local structural form combining strike-slip and reverse displacements (horizon +160 , north-western benches of quarry). Supposed model of its formation is in lower part of the figure: 1 - extension phase; 2 - compression phase.

Рис. 10. Локальная структурная форма сочетающая сбросовые и взбросовые смещения (горизонт +160, северозападные уступы карьера). В нижней части рисунка предполагаемая модель ее формирования: 1 - этап растяжения; 2 - этап сжатия.
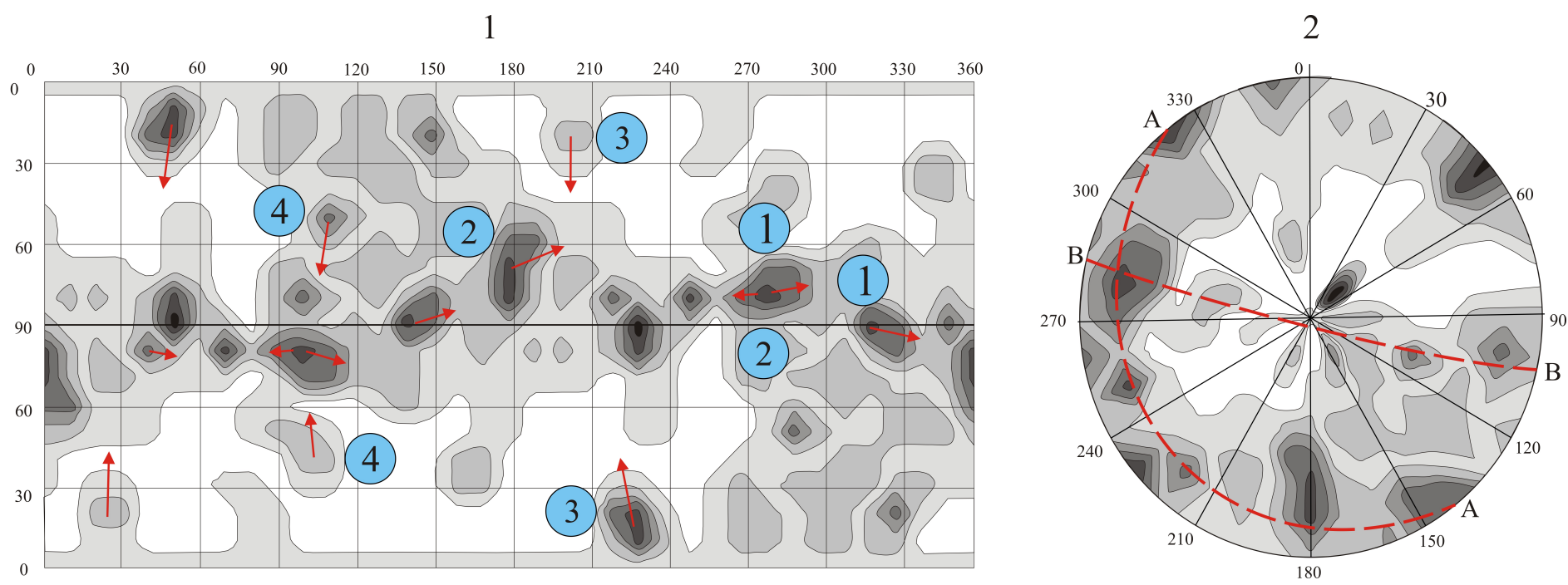

Fig. 11. Diagram of statistical measurement of fractures in the site 0705. Quarry of the Nyurbinskaya pipe.

1, 2 - circular (1) and square (2) diagrams of statistical measurement of fractures. Total 75 measurements, upper hemisphere projection, isoline pitch $1 \%$ (initial isoline - $0.5 \%$ ). In a square diagram the arrows indicate the scattering direction of the maxima fracture system [Nikolaev, 1977]. Conjugated pairs of maxima (solutions in fig. 12) are figured. Belts of fracturing (see explanations in the text) are lettered by $\mathrm{A}$ and $\mathrm{B}$ in circular diagram.

Рис. 11. Диаграммы массового замера трещин в т.н. 0705. Карьер трубки Нюрбинская.

1, 2 - круговая (1) и прямоугольная (2) диаграммы массового замера трещин. Всего 75 замеров, проекция на верхнюю полусферу, шаг изолиний $1 \%$ (начальная изолиния - $0.5 \%$ ). На прямоугольной диаграмме стрелками показано направление разбросов у максимумов систем трещин [Nikolaev, 1977]. Цифрами обозначены сопряженные пары максимумов (решения на рис. 12). На круговой диаграмме буквами А и В обозначены пояса трещиноватости (см. пояснения в тексте). 

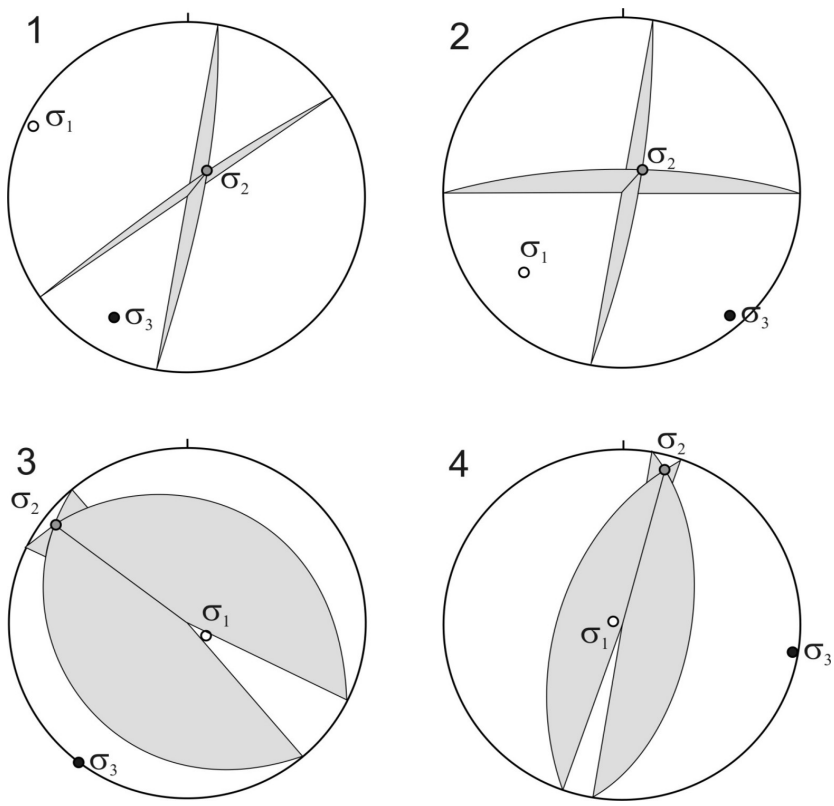

faults. The four solution indicates the sublatitudinal compression (Fig. 12, 4) that corresponds to the reverse faults displacements fixed by the NNE faults (Diagonalnyi fault zone).

Synoptic rose-diagrams of the subhorizontal compression (Fig. 13, $A$ ) and extention (Fig. 13, $B$ ) axes directions as well as combined rose-diagram with all maxima obtained appropriate to the principal normal stresses directions (Fig. 13, B) were constructed. It should be noted, that maxima of extention axes (Fig. 13,
Fig. 12. Results of reconstruction of positions of the principal normal stress axes in the site 0705 .

1-4 - solutions for conjugated pairs lettered in fig. 11, 1. Axes of principal normal stresses: $\sigma_{3}$ - compression, $\sigma_{1}-$ extension, $\sigma_{2}-$ intermediate.

Рис. 12. Результаты восстановления положения осей главных нормальных напряжений в т.н. 0705.

1-4 - решения для сопряженных пар обозначенных цифрами на рис. 11, 1. Оси главных нормальных напряжений: $\sigma_{3}-$ сжатия, $\sigma_{1}$ - растяжения, $\sigma_{2}$ - промежуточная.
$B, C$ ) necessarily correspond to the maxima of the compression axes in Fig. 13, $A, B$, but located perpendicular to the first ones. This fact indicates a significant role of the stress fields of strike-slip type in the history of the fault junction formation enclosing the Nyurbinskaya pipe that consists with the above result of the fault displacements analyses and slickensides on the fracture planes (see Fig. 9).

Thus, formation and activation of the fault structure within the Nyurbinskaya pipe location (in the upper
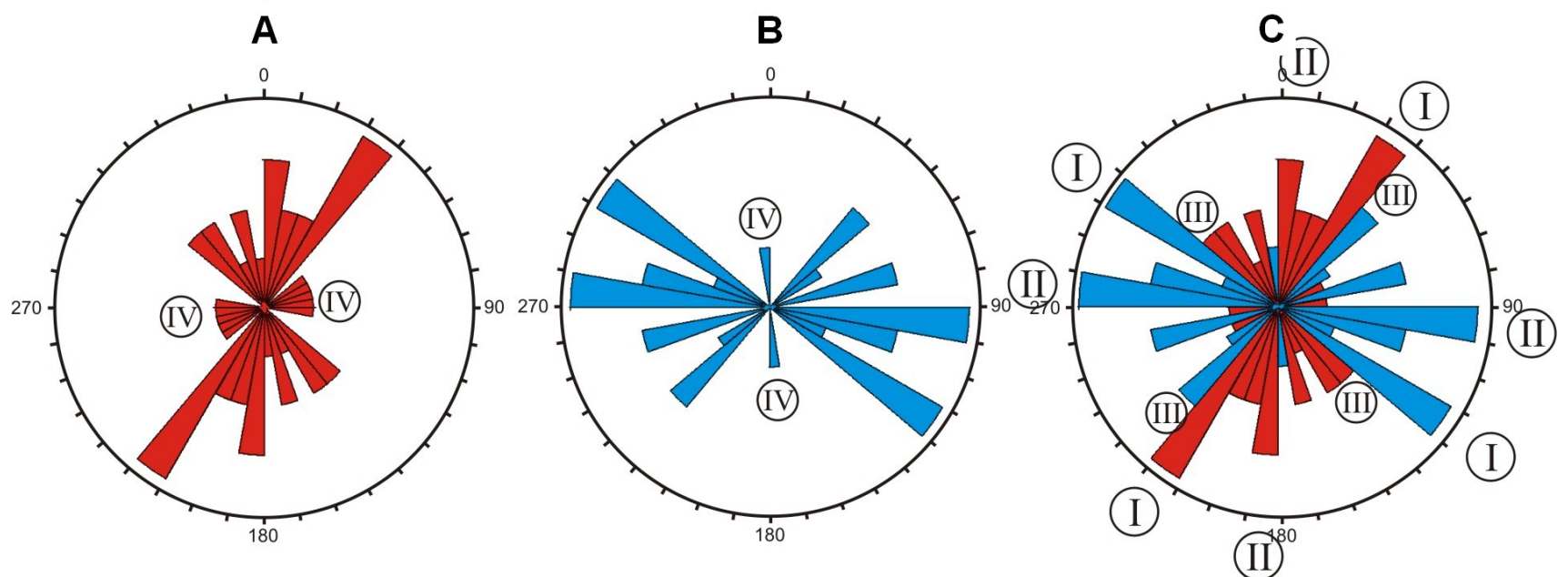

Fig. 13. Rose-diagrams of subhorizontal axes directions of the principal normal stresses for the solutions obtained in points of sight of the quarry Nyurbinsky. $A$ - compression axes; $B$ - extension axes; $C$ - combined rose-diagram (superposition of maxima of diagrams $A$ and $B$ ). Roman numerals mark the fields discussed in the text.

Рис. 13. Роза-диаграммы простирания субгоризонтальных осей главных нормальных напряжений для решений, полученных в точках наблюдения в карьере Нюрбинский. $A$ - оси сжатия; $B$ - оси растяжения; $C$ - комбинированная роза-диаграмма (наложение максимумов диаграмм $A$ и $B$ ). Римскими цифрами обозначены поля, обсуждаемые в тексте. 
part of Paleozoic sediments and Mesozoic overlying rocks) occurred during several stages differing in direction of tectonic forces action. One of them was characterized by north-eastern orientation of the compressive forces axes and by north-western orientation of the tensile forces axes (maxima I in Fig. 13, B). Another stage was characterized by submeridional compression and sublatitudinal extention (maxima II, fig, 13, B). North-west direction of the compression axis and north-eastern direction of the extention one are typical of the third stage (maxima III, fig, 13, B). And finally, during the fourth stage, the principal normal stresses axes exhibit submeridional (extention) and sublatitudinal (compression) orientations (maxima IV in Fig. 13, $A$ and Fig. 13, $B$ ).

It is believed that some of the noted fields occurred in the Paleozoic and other fields - in the Mesozoic. Formation, development and possibly partial activation of the fault structure enclosing the kimberlite body were related to the first stages. The second stage produced activation of near-pipe structure and formation of fault network in overlapping deposits. The occurrence peculiarities of vertical displacements within fault zones of different trends serves an indication of the tectonic stresses field affiliation to one or the other stage. So, normal fault displacements along faults within the Botuobinsky fault zone bearing witness to the effect of tensile force north-westward (maxima I in Fig. 13, $B$ ) occurred in the Paleozoic sediments and not noted in the Mesozoic rocks. At the same time vertical displacements of the crust of weathering and Mesozoic basal rocks are widely marked on the Shirotnyi fault pointing to submeridional orientation of tensile forces (maxima IV in Fig. 13, B). The presence of compression stresses traces imposed on the structure of extention in both mentionned zones (e.g., Fig. 10) provide evidences that stages which position of the principal normal stresses axes corresponding to I and IV maxima in Fig. 13 were in turn followed by stages for which orientations of the compression and extension axes meet III and II maxima in Fig. 13.

Thus, the overall order of the tectonic stress fields occurrence with time (and, accordingly, related stages) is as follows:

1) north-east compression - north-west extention;

2) north-west compression - north-east extention;

3) submeridional extention - sublatitudinal compression;

4) submeridional compression - sublatitudinal extention.

Of the listed fields, only the first two could have a decisive influence on the formation and development of fault structures enclosing the kimberlite body because the next two fields operated in the Mesozoic. These findings consist with the results obtained from studying the Malo-Botuobinsky and Alakit-Marhinsky areas [Gladkov et al., 2008], that may indicate a single tectonic situation that determined localization of the Middle Paleozoic kimberlite bodies within the Yakutian diamondiferous province.

\subsection{ELEMENTS OF STRUCTURAL-COMPOSITIONAL MODEL OF THE NYURBINSKAYA KIMBERLITE PIPE FORMATION}

The data presented characterize the composition of kimberlite body and enclosing tectonic structure that allowed using them as the basis for creating the elements of structural compositional model of the Nyurbinskaya kimberlite pipe formation (Fig. 14). It is proposed that the kimberlite melt localization in sediments of the upper part of the platform cover was due to the presence of the extention structures. Considering the above mentioned evidences the peculiarities of the fault activation within the studied area as well as the emplacement succession and distribution of the kimberlite pipe different phases were considered.

The pipe formation started in the stress field characterized by northeast orientation of the compression axis and northwest extension axis with emplacement of relatively extensive dikes and subvertical stock of micaceous porphyric kimberlites (PK) within the Diagonalnyi fault segments. Fault segments were activated under tension condition resulting from sinistral displacements along the Shirotnyi fault (Fig. 14, A). Local faults of the Botuobinskaya fault zone which were under tension influenced the stock formation.

S-shaped areas of tension (Fig. 14, B) appeared in the course of further activation of fault junction due to interaction of the Shirotnyi fault segments (along which the sitistral displacements went on) and local faults governing the structure of the Diagonalnyi and Botuobinsky fault zones. Within their boundaries the intense explosive processes, with predominance of gasfluid component in the kimberlite melt-fluid occurred that simultaneously with tectonic movements led to intense fracturing of sedimentary socle and filling the parts of formed cavities by kimberlite melt. Thus, small bodies of eruptive kimberlite breccias were formed within the southwestern and northwestern flanks of the pipe present-day contour.

Continuing displacement along the Shirotnyi fault segments together with explosive effect resulted in a large cavity formation in carbonate socle; the cavity was filled by autolith kimberlite breccias (AKB) (Fig. $14, C$ ). Consequently the pipe contour close to the present-day one and elongated in the NNE direction in subparallel to pre-ore dike of porphyric kimberlites was formed.

The formation of the fourth phase of the kimberlite body occurred in the changed field of tectonic stresses, the axes of compression and extention of which were directed north-westward and north-eastward, respec- 
(A)
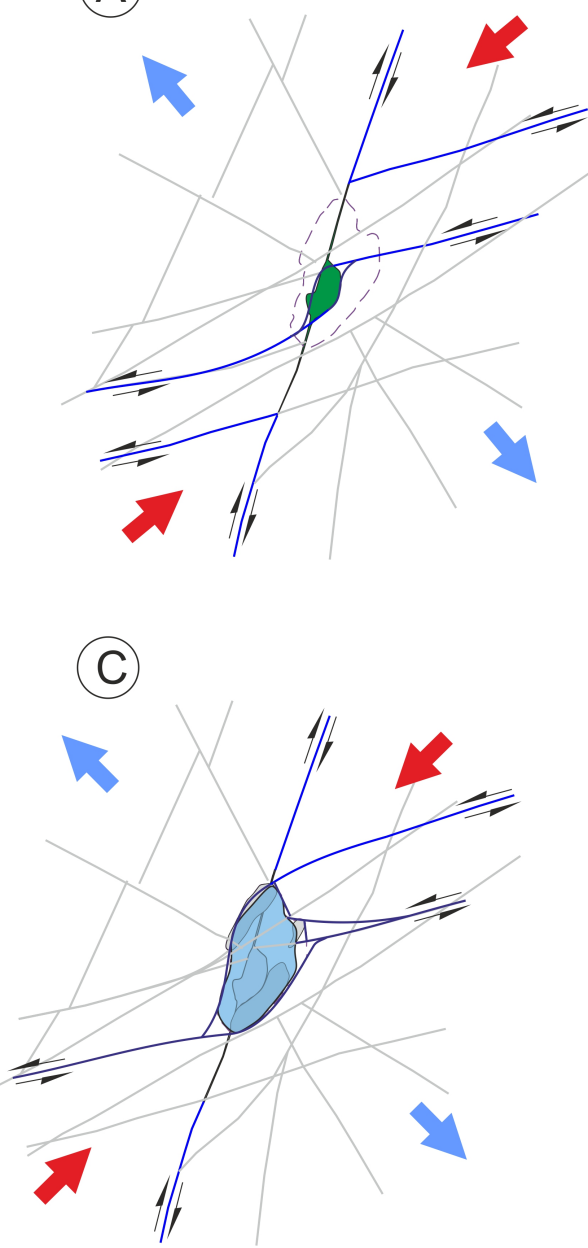
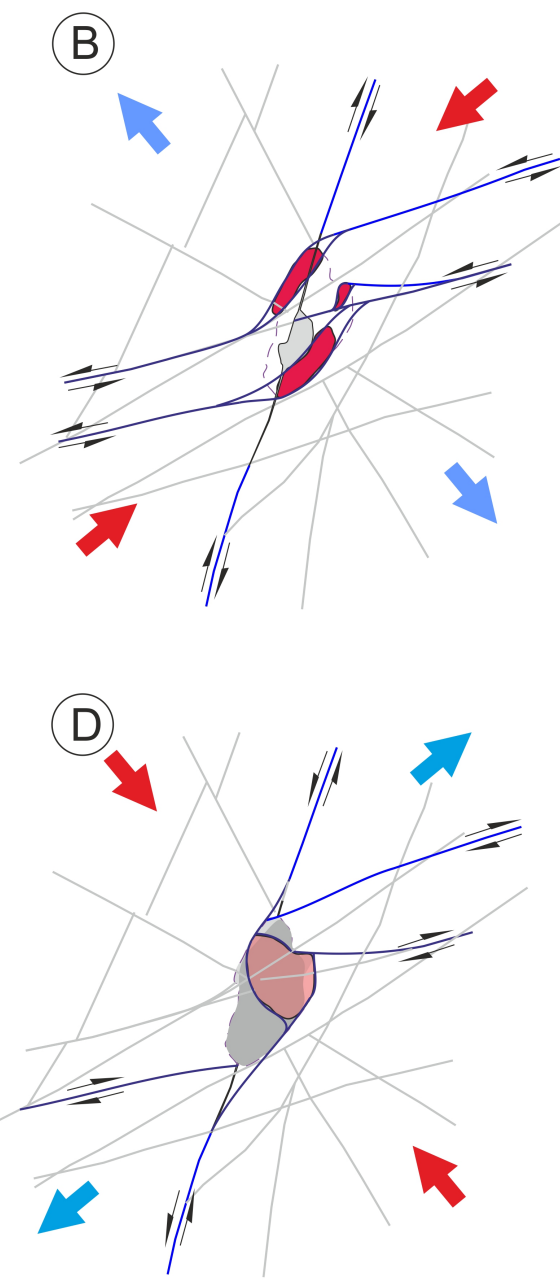

Fig. 14. Structural-compositional model of the Nyurbinskaya pipe formation in complicated fault junction resulting from alternate strike-slip motions.

Large arrows mark direction of compression (red) and extension (blue) forces action at different stages. Solid lines correspond to faults within the fault junction. Black arrows show directions of strike-slip displacements at different stages of deformation. Dotted line marks the present-day contour of ore body. Shaded areas correspond to the emplacement areas of different phases of kimberlites.

Рис. 14. Структурно-вещественная модель становления трубки Нюрбинская в сложнопостроенном разломном узле в результате знакопеременных сдвиговых движений.

Большими стрелками обозначено направление действия сил сжатия (красные) и растяжения (синие) на различных этапах Сплошные линии соответствуют разрывным нарушениям в разломном узле. Черные стрелки показывают направления сдвиговых смещений на различных этапах деформирования. Пунктирной линией обозначен современный контур рудного тела. Закрашенные области соответствуют участкам внедрения различных фаз кимберлитов.

tively. In these circumstances, the displacement signs along the Shirotnyi and Diagonalnyi faults segments were changed to opposite ones (the first operated as a dextral fault and the second operated as a sinistral one). As a result of interaction of the Diagonalnyi fault and fault segments of north-western trend (Fig. 14, D) was the tectonic factor determining the area position of maximum opening within the fault junction. There is no doubt that explosive processes whose penetrating power repeatedly increased the deformation effects of tectonic forces significantly affected the form and size of its opening. The kimberlite melt intruded the formed structure within central and northern segments of the present-day ore body contour (Fig. 14, D) and completed the Nyurbinskaya pipe formation.

\subsection{EXPERIMENTAL REPRODUCTION OF STRESS-AND-STRAIN STATE IN THE NEIGHBOURHOOD OF FAULTS OF THE NYURBINSKAYA PIPE LOCATION}

In order to verify the correctness of the proposed model structural component the experimental studies were conducted using photoelasticity method. Meanwhile, the natural network of principal faults of the 

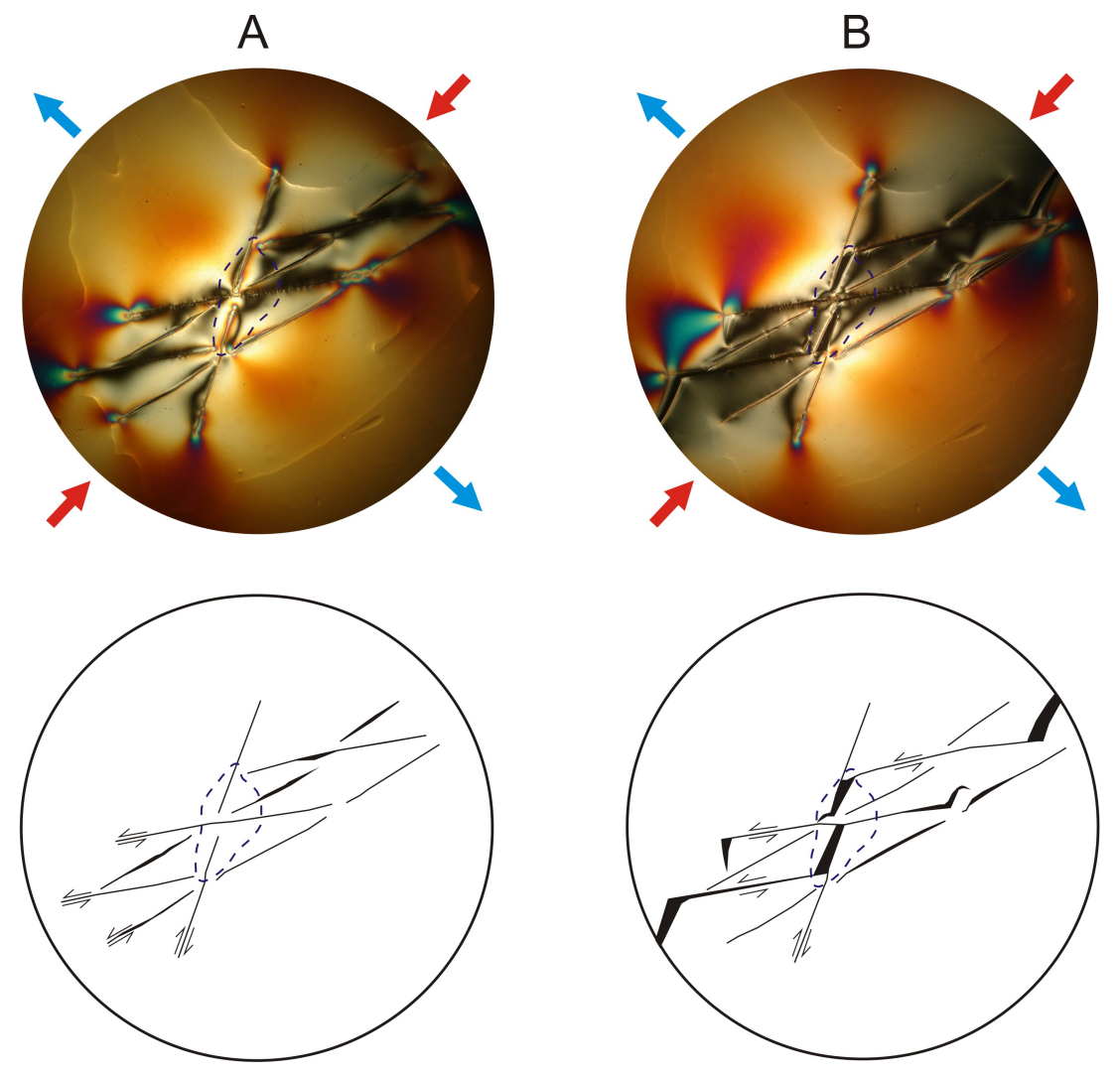

Fig. 15. Optic modeling of stress-and-strain state in the neighborhood of faults of the Nyurbinskaya pipe location under NE compression - NW extension.

$A$ and $B$ - stages of experimental procedure. Red and blue arrows - orientation of external actions at the model boundaries, black arrows direction of strike-slip displacements of the fault flanks. Dotted line marks the ore body contour in natural analog. The rest of the explanation is in the text.

Рис. 15. Оптическое моделирование напряженно-деформированного состояния в окрестностях разрывных нарушений участка локализации трубки Нюрбинская в условиях северо-восточного сжатия - северо-западного растяжения.

$A, B$ - стадии проведения эксперимента. Красные и синие стрелки - ориентировка внешних воздействий на границах модели, черные стрелки - направление сдвиговых перемещений крыльев разрывов. Пунктирной линией обозначен контур рудного тела в природном аналоге. Остальные пояснения в тексте.

Nyurbinskaya pipe location was simulated which during experimental procedure was subjected to external influences, appropriate by orientation of operating forces to one of the four tectonic stress fields established in the course of geological structural analysis. Experimental works were focused on recording the results of elastic interaction of the faults sides and stress changes simultaneousely occurred. The first experiment reflected conditions appropriate to north-east direction of the compression axis and north-west direction of the extension axis. The model reproduced the network of the Diagonalnyi, Shirotnyi and Botuobinsky faults. The rupture dislocations at the first phase of this and all subsequent experiments the faults were isolated (not linked and intersected). When loading the opening displacements along the Botuobinsky fault zone, dextral strike-slip faults along the Diagonalnyi fault and sinistral strike-slips faults along the Shirotnyi fault system (Fig. 15, $A$ ) were registered in gelatinous model. The following stage is characterized by the faults intergrowth and their integration into a single coherent fault and block structure. In this case the stress and strain field of the model was significantly redistributed (Fig. 15, B). The value of dextral movements along the Diagonalnyi fault was consistent with that of mouvements at the first stage of experiment. At the same time the fault displacements of the Shirotnyi fault flanks increase resulting in the opening of the Diagonalnyi fault central segments (Fig. 15, B). In addition, the Shirotnyi faults here and there are slightly opened, but a sinistral component of displacement substantially prevails. Recorded in the experiment the response peculiarities of fault network to external action confirms in general the proposed process of the structure 
A
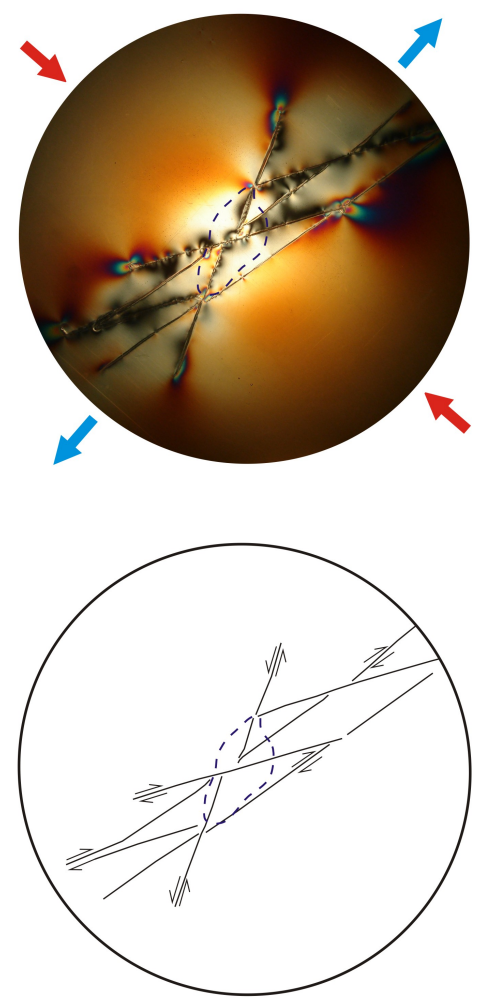

B
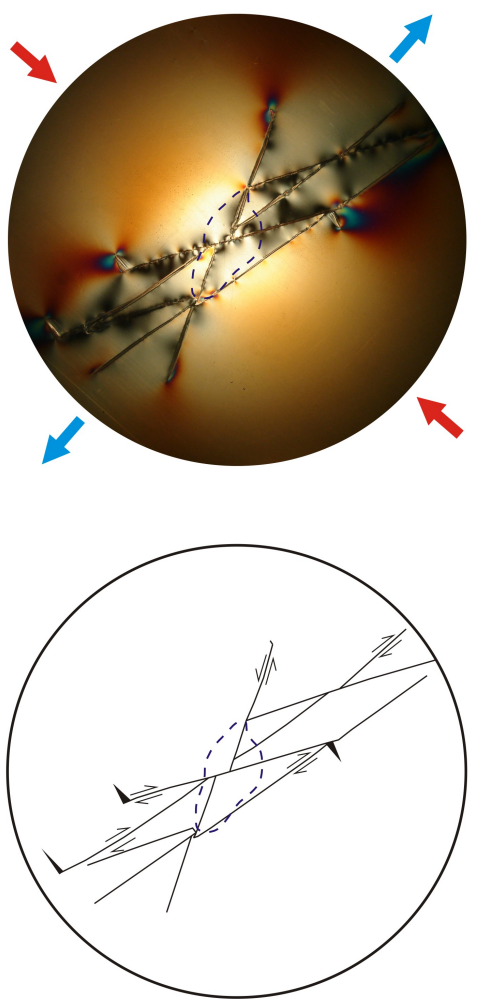

Fig. 16. Optic modeling of stress-and-strain state in the neighborhood of faults of the Nyurbinskaya pipe location under NW compression - NE extension. $A$ and $B$ - stages of experimental procedure. Symbols are similar to Fig. 15.

Рис. 16. Оптическое моделирование напряженно-деформированного состояния в окрестностях разрывных нарушений участка локализации трубки Нюрбинская в условиях северо-западного сжатия - северо-восточного растяжения. $A, B$ - стадии проведения эксперимента. Условные обозначения аналогичны рис. 15.

development at the first three stages of the structuralcompositional model of the Nyurbinskaya pipe formation.

The second experiment reproduced the NW orientation of the compression axis and NE of the extention one. At the first stage of the experiment the most extensive central fault of the ENEe orientation displaces substantially (per $1 / 9$ of proper length) the Diagonalnyi fault after the dextral strike-slip fault (Fig. 16, A). The Botuobinsky fault under these boundary conditions of the model loading develops as sinistral strikeslip fault with very little displacement of flanks. In whole, under this method of load application the faults sides were closed: i.e. opening displacements of flanks were not observed. This situation was not significantly changed at the second stage at cooperative behavior of interrelated faults (Fig. 16, B). That is that the structure opening in the area central part was not observed as the developed structural-compositional model proposed.

We proposed that the main discrepancy between the proposed structural-compositional model and experimental data is due to the absence of the fault of NW orientation. Therefore, an additional experiment has been conducted which showed that addition of the NW fault in the model on exposure to north-western compression and north-eastern extention allows to obtain the necessary structures for the opening within the area of the central kimberlite body (Fig. 17). Opening structures are observed on model as in the case of relatively simple combinations of faults of the NW and NNE orientations (Fig. 17, A) and when complicating the junction structure to its full configuration (Fig. 17, $B-$ $D$ ). Thus, the results of the additional experiment confirm the proposed opening mechanism for the fourth phase of the structural-compositional model.

In general, one can state that the experimental data suggest the legitimacy of structural component of the model. They show that opening and strike-slip fault structures enclosing the Nyurbinskaya pipe are the result of cooperative behavior and interaction of the faults of different directions that is typical of the fault junctions [Cheremnykh, 2010]. The addion or removal of one or another faults from the model results in substantial redistribution of local tensions inside the fault network and, consequently, in significant change 
A
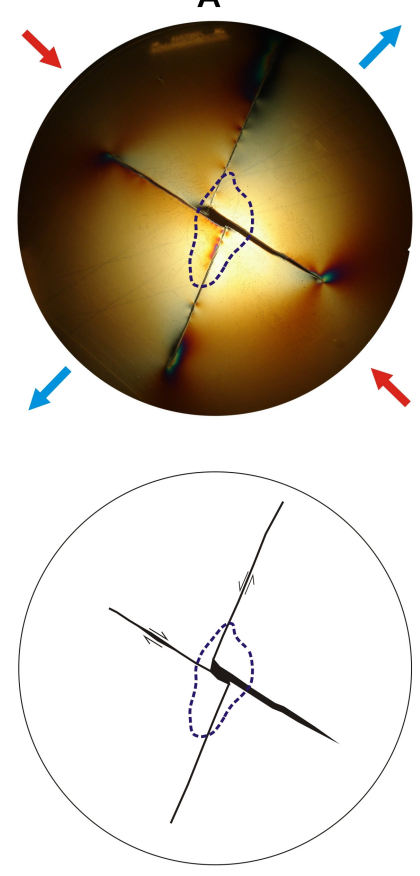

B
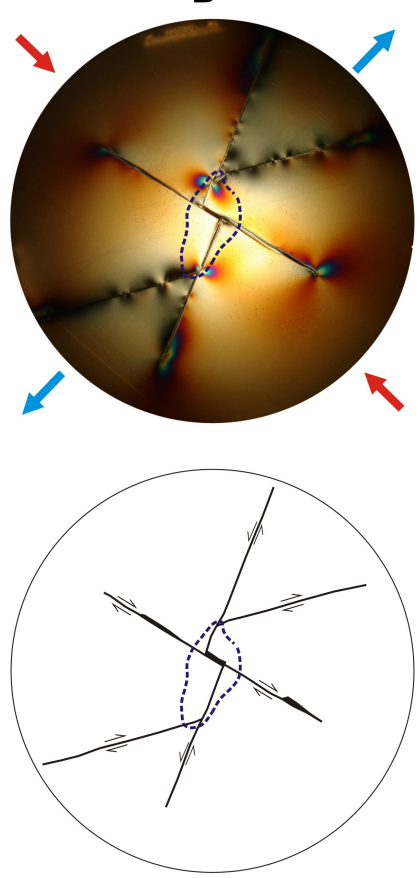

C
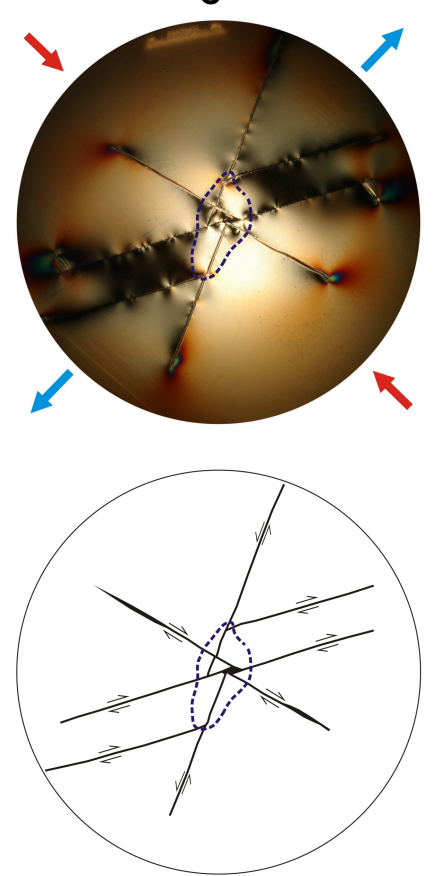

D
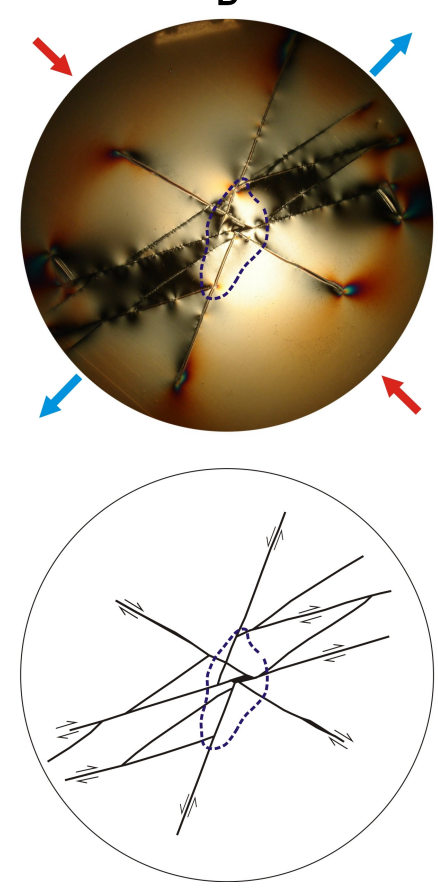

Fig. 17. Optic modeling of stress-and-strain state in the neighborhood of faults of the Nyurbinskaya pipe location under NW compression - NE extension. A-D - stages of experiment. Symbols are similar to Fig. 15.

Рис. 17. Оптическое моделирование напряженно-деформированного состояния в окрестностях разрывных нарушений участка локализации трубки Нюрбинская в условиях северо-западного сжатия - северо-восточного растяжения. A-D - стадии проведения эксперимента. Условные обозначения аналогичны рис. 15.

of the faults opening segments, as well as of their amplitudes.

\section{DISCUSSION}

The developed model (see Fig. 14) allowed in whole to link the observed peculiarities of location and kinematics of faults and regularities of compositional structure and form of the Nyurbinskaya pipe in the contect of within the framework of the functioning of a single tectonodynamic system. This assumes that the position of kimberlite bodies within sedimentary cover was determined by activation of the fault network of the area exposed to regional tectonic stress field which in turn is derivative of the deep tectono-magmatic processes. The emplacement proper of kimberlite body occurs in conditions of dynamic interaction of tectonic forces and forces appearing from on sedimentary layers by the melt-fluid that intruded them. The first of them cause the occurrence of "weakened" structural elements that provide promotion of kimberlites in the upper part of the cover and predetermine the position of pipes. The latter contributed to the marked increase of deformations (rock crushing and removal of crushed products), fast ascent of kimberlite magma and filling of open cavities "prepared" by tectonics and "cleaned" in the course of explosive processes.

Structural-compositional model and its experinental verification that illustrated a cooperative role of the different orientations faults in the enclosing kimberlite body formation have also obvious practical significance. On their basis we proposed for the Nakyn field a structural image of the prospecting object - i.e. the area within which the location of kimberlite body of the Nyurbinskaya pipe type is possible. This is the intersection junction of regional faults of the NNE, NE and ENE directions as well as a local fault of the NW trend. The presence of the first three fault directions is obligatory.

The given image was used for a reappraisal of the Nakyn field central part for the presence of structural elements favorable according their structures to localization of kimberlite body of the Nyurbinskaya pipe type. The scheme of fault tectonics setted up on data of magnetic and seismic prospectings by specialists the Botuobinskaya GPE of AC "ALROSA" PC geological prospecting expedition and supplemented by findings of structural decoding was used for analysis. The fault junctions promising for discovery of kimberlite bodies of the Nyurbinskaya pipe type are indicated on it (Fig. 18). As illustrated in Fig. 18, not all intersections of the fault zones fit all the criteria resulted from the 


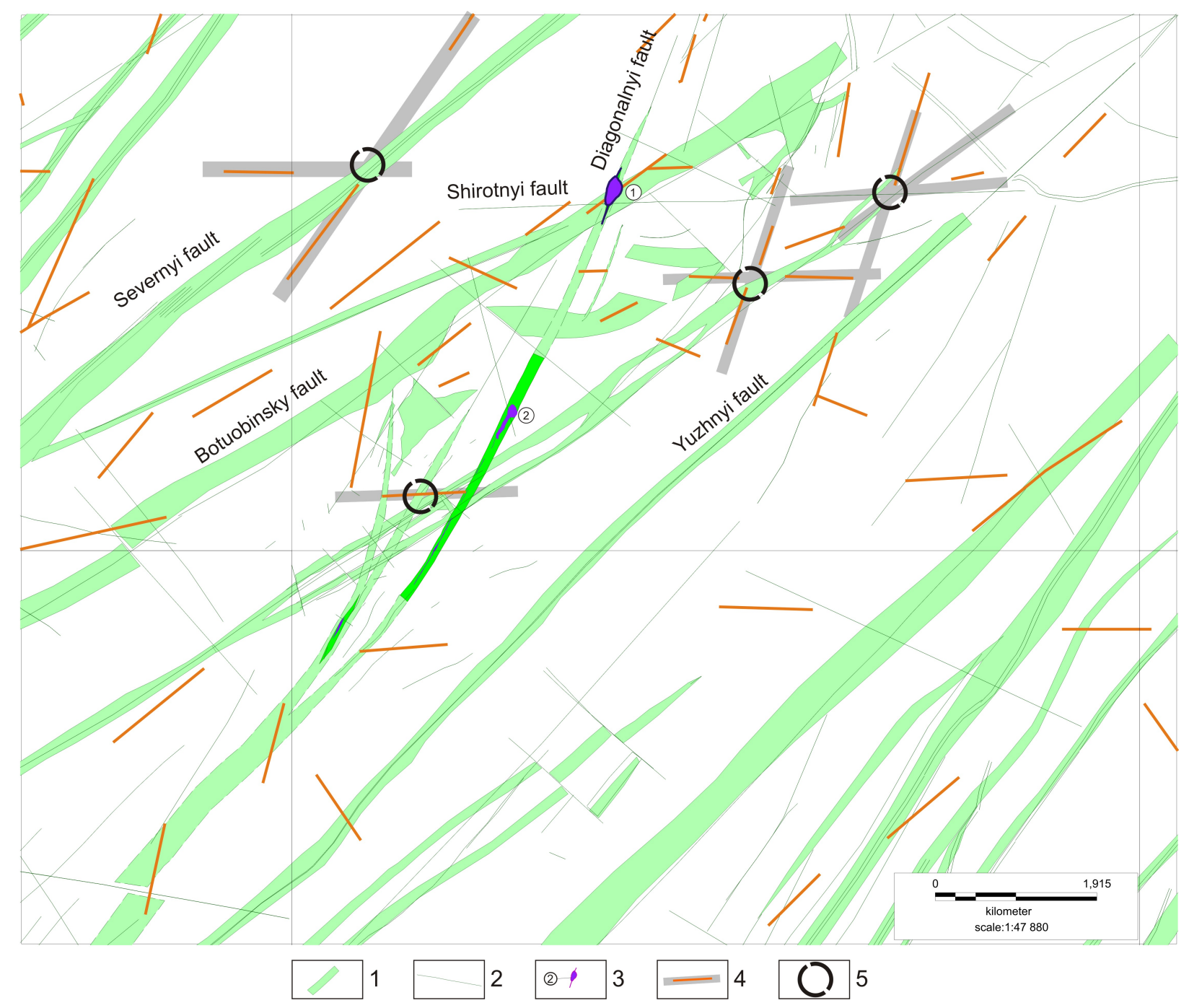

Fig. 18. Scheme fragment of fault tectonics of the Nakyn kimberlite field (on data of geophysical service of BGPE AC ALROSA PC) with addition of structural decoding results.

1 - zones of large faults; 2 - faults of different scales; 3 - kimberlite bodies: 1 - Nyurbinskoye, 2 - Botuobinskoye; 4 - lineaments recognized by structural decoding results; 5 - junctions of faults promising (by geologo-structural characteristics) for discovery of kimberlite bodies of the Nyurbinskaya pipe type.

Рис. 18. Фрагмент схемы разломной тектоники Накынского кимберлитового поля (по данным геофизической службы БГРЭ АК АЛРОСА ОАО), с дополнением результатов структурного дешифрирования.

1 - зоны крупных разломов; 2 - разрывные нарушения различных масштабов; 3 - кимберлитовые тела: 1 - Нюрбинское, 2 Ботуобинское; 4 - линеаменты, выделенные по результатам структурного дешифрирования; 5 - узлы разломов, перспективные по геолого-структурным признакам, на обнаружение кимберлитовых тел типа трубки Нюрбинская.

structural-compositional model development. At present level of knowledge about tectonic structure of the Nakyn kimberlite field area only four fault junctions are fitted them within the analysed area (Fig. 18). All they are formed by faults of the NE, NNE and sublatitudinal (ENE) trends. It should be emphasized that given junctions meet only part of the above description of the potential kimberlite enclosing structures, namely, the composition of thefault junction. Verification of recognized structures by geophysical and/or drilling works is required for the final assessment of the prospects for each of them and localization of potential kimberlite bodies.

At the same time in the context of the model some questions requiring clarification occurred. First of all it concerns the time and and tectonic stress rate at different stages of the Nyurbinskaya pipe formation. As indicated above, the distances between the melt portions emplacement appeared to be small (kimberlite emplacement of next phase occurred in the not yet completely consolidated previous phase). That is the change of the tectonic stress field at the last stage of the 
pipe formation there was almost instantly (on a geological time scale) that is more in line with pulse nature of the tectonic stress field occurrences. Another feature of the model, requiring further study is that of the structure formation containing kimberlite body results from preferential activation of individual segments of the faults in the fault junction (see Fig. 14). Therefore one of the purposes of further research is a diagnosis of causes and mechanisms of such preferential activation of elements of the fault junction. The problem solving may allow presorting of prospective fault junctions on the basis to what extent the activation reguliarities of the fault segments meet the structural-compositonal model of the kimberlite pipe formation.

\section{CONCLUSION}

The works performed in the Nyurbinskaya pipe quarry allowed for the first time to undertake a comprehensive analysis of compositional and structural components in the deposit structure. It is established that the pipe is confined to the fault junction and is composed of kimberlites of four phases of emplacement that formed subsequently the ore body presentday form. Structure of the fault junction is described and fields of tectonic stresses determined its revitalization during different time intervals (including the time of the kimberlite body emplacement). The data obtained underlain the structural-compositonal model of the Nyurbinskaya kimberlite pipe formation thatcorrelated the observed peculiarities of the spatial position of different kimberlite phases to activation of single segment of the fault junction in the context of a single tectono-dynamic system operation. Physical modeling on optically active materials confirned the proposed in the structural-compositonal model the behavior of different elements of the fault junction in response to the affect of their stresses which according to direction by forces matched natural fields of tectonic stresses which took place during the kimberlite body formation.

Developped model allowed to state the structural features defining characteristics of the prospecting works object within which the formation of kimberlite bodies of Nyurbinskaya pipe type is possible and on their basis to recognize the elements of the fault network (fault junctions) that are promising for the kimberlite pipes discovery. In this case it is essential that the given structural characteristics meet only tha large objects of the Nyurbinskaya pipe type. In order to develop the geologo-structural characteristics and criteria characterizing the position of smaller objects of the Botuobinskaya, Markhinskaya and Maiskaya pipes type within the Nakyn diamondiferous field it is necessary to consider the details of tectonic structure of their location and conduct experimental works in order to study the formation mechanism of kimberlite enclosing structure. Currently available data suggest that similar bodies correspond to the fault junctions of more simple structure and which form the faults of the NNE direction (required element) and faults of one of the directions typical of the area: ENE or NW or NE directions.

\section{ACKNOWLEDGMENTS}

The work is finantially supported by the AC "ALROSA" PC.

\section{REFERENCES}

Bogatikov O.A., Kononova V.A., Golubeva Y.Y., Zinchuk N.N., Ilupin I.P., Rotman A.Y., Levsky L.K., Ovchinnikova G.V., Kondrashov I.A., 2004. Variations in chemical and isotopic compositions of the Yakutian kimberlites and their causes. Geochemistry International 42 (9), 799-821.

Cheremnykh A.V., 2010. Fault-block structure and the stress state of the upper crust of lake Baikal's eastern coast (field observations and modeling). Izvestiya, Physics of the Solid Earth 46 (5), 404-411. http://dx.doi.org/10.1134/ S1069351310050058.

Chernyi S.D., Fomin A.S., Yanygin Yu.T., 1998. Geological structure and composition of kimberlite pipes of the Nakyn field of the Yakutian province. In: Geology, distribution pattern, methods of prediction and prospecting for diamond deposits. Mirny, p. 157-159 (in Russian) [Черный С.Д., Фомин А.С., Яныгин Ю.Т. Геологическое строение и вещественный состав кимберлитовых трубок Накынского поля Якутской провинции // Геология, закономерности размещения, методы прогнозирования и поисков алмазных месторождений алмазов. Мирный, 1998. С. 157-159].

Danilovich V.N., 1961. Method of Belts in Study of Fracturing Related to the Fault Displacements. Irkutsk Polytechnic Institute, Irkutsk, 47 p. (in Russian) [Данилович B.H. Метод поясов в исследовании трещиноватости, связанной с разрывными смещениями. Иркутск: Иркутский политехнический институт, 1961. 47 с.].

Gladkov A.S., Bornyakov S.A., Manakov A.V., Matrosov V.A., 2008. Tectonophysic Studies During Prospecting for Diamonds. Learner's guide. Nauchnyi mir, Moscow, 175 p. (in Russian) [Гладков А.С., Борняков С.А., Манаков А.В., Матросов B.A. Тектонофизические исследования при алмазопоисковых работах. Методическое пособие. М.: Научный мир, 2008. 175 с.].

Gladkov A.S., Seminskii K.Zh., 1999. Nontraditional analysis of fracturing belts on mapping of subhorizontal fault structures (exemplified by the vicinities of Irkutsk). Geologiya i Geofizika (Russian Geology and Geophysics) 40 (2), 213220. 
Gzovsky M.V., 1975. Fundamentals of Tectonophysics. Nauka, Moscow, 536 p. (in Russian) [Гзовский М.В. Основы тектонофизики. М.: Наука, 1975. 536 c].

Ignatov P.A., Bushkov K.Yu., Tolstov A.V., Yuanygin Yu.T., 2008. Mapping of cryptic strike-slip kimberlite-controlling structures in the Nakyn field. In: Problems of prediction and prospecting of diamond deposits within covered territories. Proceedings of Conference dedicated to the 40 anniversary of YaNIGP TsNIGRI AC "ALROSA". Publishing House of YaSC SB RAS, Yakutsk, p. 325-332 (in Russian) [Игнатов П.А., Бушков К.Ю., Толстов А.В., Яныгин Ю.Т. Картирование скрытых сдвиговых кимберлитоконтролирующих структур в Накынском поле // Проблемы прогнозирования и поисков месторождений алмазов на закрытых территориях: Материалы конференции, посвященной 40-летию ЯНИГП ЦНИГРИ АК “АЛРОСА”. Якутск: Изд-во ЯНЦ СО РАН, 2008. С. 325-332].

Kharkiv A.D., Zinchuk N.N., Kryuchkov A.I., 1998. Primary Diamond Deposits of the World. Nedra, Moscow, 555 p. (in Russian) [Харькив А.Д., Зинчук Н.Н., Крючков А.И. Коренные месторождения алмазов мира. М.: Недра, 1998. 555 c.].

Kondratiev A.A., Gorev N.I., 2005. Tectonic structure and development history of the Sredne-Markha diamond-bearing region of the Western Yakutia. In: Geology of diamond - the present and the future (geologists to the 50-year anniversary of the Mirnyi and the diamond industry in Russia). Voronezh state university, Voronezh, p. 95-104 (in Russian) [Кондратьев А.А., Горев Н.И. Тектоническое строение и история развития Средне-Мархинского алмазоносного района Западной Якутии // Геология алмаза - настоящее и будущее (геологи к 50-летнему юбилею г. Мирный и алмазодобывающей промышленности России). Воронеж: Воронежский государственный университет, 2005. С. 95-104].

Kropotkin P.N., Yefremov V.N., Makeev V.M., 1987. Stress state of the Earth's crust and geodynamics. Geotektonika (Geotectonics) (1), 3-24 (in Russian) [Кропоткин П.Н., Ефремов В.И., Макеев В.М. Напряженное состояние земной коры и геодинамика // Геотектоника. 1987. № 1. С. 3-24].

Leonov Yu.G., 1995. Stresses in lithosphere and intraplate tectonics. Geotektonika (Geotectonics) (6), 3-21 (in Russian) [Леонов Ю.Г. Напряжения в литосфере и внутриплитная тектоника // Геотектоника. 1995. № 6. С. 3-21].

Nikolayev P.N., 1977. Statistical analysis technique for fractures and reconstruction of the tectonic stresses fields. Izvestiya VUZov, Geologiya i Razvedka (Proceedings of Universities, Geology and Exploration) (12), 103-115 (in Russian) [Николаев П.Н. Методика статистического анализа трещин и реконструкции полей палеонапряжений // Известия вузов. Геология и разведка. 1977. № 12. С. 103-115].

Osokina D.N., 1963. Plastic and Elastic Low-Modular Optically Active Materials for the Stress Study in the Earth Crust by Modeling. USSR Academy of Sciences Publishing House, Moscow, 196 p. (in Russian) [Осокина Д.Н. Пластичные и упругие низкомодульные оптически-активные материалы для исследования напряжений в земной коре методом моделирования. М.: Изд-во АН СССР, 1963. 196 с.].

Sablukov S.M., Sablukova L.I., Stegnitsky Yu.B., Karpenko M.A., Neustroev R.G., 2010. Kimberlites and basalts with differing age of the Nyurbinskaya pipe (Nakyn field, Yakutia): a portrayal of regional upper mantle evolution from the Riphean to the Carboniferous time, and its geodynamic relationships. In: Geochemistry of magmatic rocks - 2010. Abstracts of XXVII International Conference School “Geochemistry of Alkaline rocks”. Moscow-Koktebel', p. 152-153.

Sablukov S.M., Sablukova L.I., Stegnitsky Yu.B., Karpenko M.A., Spivakov S.V., 2008. Volcanic rocks of the Nyurbinskaya pipe: a reflection of the upper mantle state in the region from the Riphean to Carbon, geodynamic consequences. In: Proceedings of VIII international seminar "Deep magmatism, its sources and plumes". Irkutsk, p. 132-165 (in Russian) [Саблуков С.М., Саблукова Л.И., Стегницкий Ю.Б., Карпенко М.А., Спиваков С.В. Вулканические породы трубки Нюрбинская: отражение состояния верхней мантии региона от рифея до карбона, геодинамические следствия // Труды VIII Международного семинара «Глубинный магматизм, его источники и плюмы». Иркутск, 2008. С. 132-165].

Seminsky K.Zh., Gladkov A.S., Lounina O.V., Tougarina M.A., 2005. Internal Structure of Continental Fault Zones. Applied aspect. Publishing House of SB RAS, Branch “Geo", Novosibirsk, 293 p. (in Russian) [Семинский К.Ж., Гладков А.С., Лунина O.В., Тугарина М.A. Внутренняя структура континентальных разломных зон. Прикладной аспект. Новосибирск: Издательство СО РАН, Филиал «Гео», 2005. 293 с.].

Tolstov A.V., Minin V.A., Vasilenko V.B., Kuznetsova L.G., Razumov A.N., 2009. A new body of highly diamondiferous kimberlites in the Nakyn field of the Yakutian kimberlite province. Russian Geology and Geophysics 50 (3), 162-173. http://dx.doi.org/10.1016/j.rgg.2008.09.001.

Tomshin M.D., Fomin A.S., Kornilova V.P., Chernyi S.D., Yanygin Y.T., 1998. Peculiarities of magmatic formations from the Nakyn kimberlite field of the Yakutian province. Geologiya i Geofizika (Russian Geology and Geophysics) 39 (12), 1693-1703.

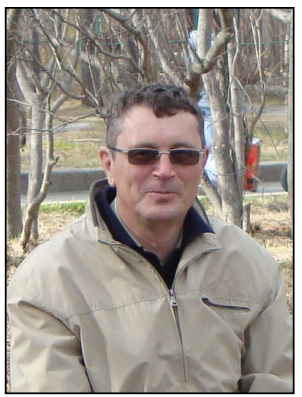

Gladkov, Andrey S., Candidate of Geology and Mineralogy

Institute of the Earth's Crust, Siberian Branch of RAS

128 Lermontov street, Irkutsk 664033, Russia

Tel.: +79148852428; \ e-mail: gladkov@crust.irk.ru

Гладков Андрей Станиславович, канд. геол.-мин. наук

Институт земной коры СО РАН

664033, Иркутск, ул. Лермонтова, 128, Россия

Тел.: +79148852428; \ e-mail: gladkov@crust.irk.ru 

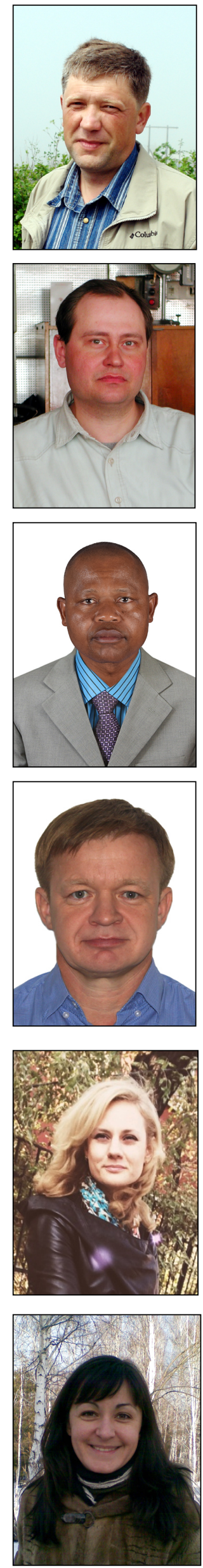

Koshkarev, Denis A., Candidate of Geology and Mineralogy Institute of the Earth's Crust, Siberian Branch of RAS 128 Lermontov street, Irkutsk 664033, Russia

Tel.+79149464704; e-mail: koshckar@crust.irk.ru

Кошкарев Денис Анатольевич, канд. геол.-мин. наук Институт земной коры СО РАН

664033, Иркутск, ул. Лермонтова, 128, Россия

Тел. +79149464704; e-mail: koshckar@crust.irk.ru

Cheremnykh, Alexander V., Candidate of Geology and Mineralogy, Senior Researcher Institute of the Earth's Crust, Siberian Branch of RAS

128 Lermontov street, Irkutsk 664033, Russia

Tel.: 89501404851; e-mail: cherem@crust.irk.ru

Черемных Александр Викторович, канд. геол.-мин. наук, с. н. с.

Институт земной коры СО РАН

664033, Иркутск, ул. Лермонтова, 128, Россия

Тел.: 89501404851; e-mail: cherem@crust.irk.ru

João, Francisco, Head of the Mineralogical Laboratory

Sociedade Mineira de Catoca (Catoca Ltd.)

Luanda Sector Talatona, Luanda Sul, Angola

Tel.: (+244 222)676700; e-mail: francisco_joao@catoca.com

Жоао Франциско, руководитель минералогической лаборатории

Горнорудное общество Катока (ГРО Катока)

Провинция Луанда-Сул, Республика Ангола

Тел.: (+244 222)676700; e-mail: francisco_joao@catoca.com

Karpenko, Michael A., Chief Geologist of Nyurba Mining and Processing Division of ALROSA, Head of operational Department of Geology "Catoca” Ltd.

$\mathrm{SC}$ «ALROSA» $(\mathrm{PC})$

20B Leningradsky prospect, Mirny 678170, Republic of Sakha (Yakutia), Russia

Tel.: +7(41136)91620; e-mail: KarpenkoMA@alrosa.ru

Карпенко Михаил Анатольевич, главный геолог Нюрбинского ГОКа АК «АЛРОСА»,

Начальник отдела эксплутационной геологии ГРО «Катока» АК «АЛРОСА»

678170, Республика Саха (Якутия), Мирный, Ленинградский проспект, 20Б, Россия

Тел.: +7(41136)91620; e-mail: KarpenkoMA@alrosa.ru

Marchuk, Marina V., Candidate of Geology and Mineralogy, Junior Researcher Institute of the Earth's Crust, Siberian Branch of RAS

128 Lermontov street, Irkutsk 664033, Russia

Марчук Марина Валерьевна, канд. геол.-мин. наук, м.н.с.

Институт земной коры СО РАН

664033, Иркутск, ул. Лермонтова, 128, Россия

Potekhina, Inna A., Candidate of Geology and Mineralogy, Junior Researcher Institute of the Earth's Crust, Siberian Branch of RAS

128 Lermontov street, Irkutsk 664033, Russia

e-mail: ip@crust.irk.ru

Потехина Инна Александровна, канд. геол.-мин. наук, м.н.с.

Институт земной коры СО РАН

664033, Иркутск, ул. Лермонтова, 128, Россия

e-mail: ip@crust.irk.ru 